\title{
WSTEPPNE PROJEKTOWANIE PROFILU MISYJNEGO DLA LOTNICZO-RAKIETOWEGO SYSTEMU WYNOSZENIA MINIATUROWYCH ŁADUNKÓW ORBITALNYCH
}

\author{
Aleksander Olejnik, Robert Rogólski, Piotr Bartnicki \\ Wojskowa Akademia Techniczna, Wydziat Mechatroniki, Uzbrojenia i Lotnictwa, Warszawa \\ e-mail: aleksander.olejnik@wat.edu.pl; robert.rogolski@wat.edu.pl; piotr.bartnicki@student.wat.edu.pl
}

\begin{abstract}
Celem rozważań zaprezentowanych w niniejszym opracowaniu było wstępne wyznaczenie profilu misyjnego dla lotniczo-rakietowego systemu wynoszenia ładunków orbitalnych oraz ocena możliwości wykorzystania myśliwca MiG-29 jako transportera rakiety z użytecznym ładunkiem. Koncepcja transportowania miniaturowych satelitów za pomocą rakiet wystrzeliwanych z samolotów po osiągnięciu pewnego pułapu staje się coraz bardziej atrakcyjna ze względu na postępującą miniaturyzację urządzeń elektronicznych (a tym samym wynoszonych obiektów), co pociąga za sobą wzrost opłacalności takich przedsięwzięć. Przedstawiony zarys misji opracowano na podstawie podobnych historycznych koncepcji. Wykorzystując odpowiednią dokumentację eksploatacyjną samolotu MiG-29, analitycznie oszacowano zużycie paliwa w locie z podwieszoną hipotetyczną rakietą. Dodatkowo za pomocą specjalistycznego środowiska symulacyjnego Aircraft Performance Program (APP) zbadano profil misji w locie z rzeczywistą rakietą ILR-33 Bursztyn, uzyskując wartości zużycia paliwa bardzo podobne do tych wyznaczonych drogą analityczną. W obu przypadkach samolot MiG-29 zużywa ok. 50\% początkowej ilości paliwa, co dowodzi, że pod tym względem istnieje niewątpliwy potencjał wykorzystania tego myśliwca w perspektywie programu misyjnego.
\end{abstract}

\section{Koncepcja systemu i jej historyczny kontekst}

Koncepcja lotniczo-rakietowego systemu wynoszenia ładunku satelitarnego na bliższą orbitę okołoziemską uwzględnia wyekspediowanie w przestrzeń obiektu latającego realizującego misję wyniesienia masy użytecznej w toku trzech etapów lotu:

- przelot samolotu z zamocowaną do płatowca rakietą nośną ma maksymalną wysokość,

- przelot odłączonej od samolotu rakiety na pułap orbitalny,

- separacja ładunku satelitarnego od rakiety i utrzymanie go na trajektorii orbitalnej.

Zastosowanie takiego rozwiązania podyktowane jest perspektywą minimalnego przyrostu prędkości rakiety, która jest potrzebna do wyniesienia satelity na orbitę. Wynika to oczywiście z prędkości, którą już posiada samolot w momencie odstrzelenia rakiety na wysokości kilkunastu kilometrów. Wielkość ta oznaczana jako $\Delta V$ może być interpretowana jako swoista miara zasięgu aparatu kosmicznego. Określana jest zależnością nazywaną wzorem Ciołkowskiego [2]

$$
\Delta V=V_{e} \ln \frac{m_{0}}{m_{k}}
$$

gdzie: $m_{0}$ - całkowita masa startowa rakiety, $m_{k}$ - masa pasywna (końcowa) rakiety, $V_{e}-$ prędkość wylotowa gazów.

Konwencjonalny start rakiety z Ziemi wiąże się z koniecznością pokonania dolnych warstw atmosfery. Opory aerodynamiczne przyczyniają się do spalenia znacznych ilości paliwa, zanim rakieta osiągnie pułap docelowy. Gęstość powietrza atmosferycznego oczywiście maleje ze wzrostem wysokości - według atmosfery wzorcowej na pułapie około $10 \mathrm{~km}$ stanowi niespełna $30 \%$ 
gęstości przy powierzchni Ziemi. Brak konieczności przedzierania się rakiety przez najgęstszą część atmosfery powoduje zużycie mniejszej ilości paliwa, a tym samym generuje oszczędność masy. Zredukowane zostają także oddziaływanie grawitacyjne oraz opory związane z manewrowaniem rakietą z racji skrócenia czasu jej przelotu [1].

W przypadku lotów w zakresie prędkości poddźwiękowych zastosowanie kombinacyjnego systemu samolot-rakieta gwarantuje redukcję prędkości $\Delta V$ na poziomie $300 \div 900 \mathrm{~m} / \mathrm{s}$. Rakiety stosowane w takich systemach mogą - lecz nie muszą - powierzchnie generujące dodatkową siłę nośną. Dodatkowe powierzchnie aerodynamiczne mogą wówczas umożliwić obniżenie niezbędnego przyrostu prędkości $\Delta V$ o dodatkowe $100 \div 200 \mathrm{~m} / \mathrm{s}$ w porównaniu do rakiety bez skrzydeł. Odpalenie silnika rakiety powinno odbyć się na maksymalnej możliwej wysokości, którą samolot jest w stanie osiągnąć. Trzeba mieć jednak na uwadze, że efektywność proponowanego rozwiązania jest opłacalna w przypadku podwieszenia (ewentualnie nawieszenia) rakiet o stosunkowo niewielkich wagomiarach. Przy masie rakiety rzędu kilkuset kilogramów należy mieć na względzie, że masa wynoszonego ładunku orbitalnego nie powinna przekraczać $30 \mathrm{~kg}$. Dlatego też system wynoszenia oparty na hybrydowym lotniczo-rakietowym sposobie transportu ładunków satelitarnych jest najbardziej właściwy do wynoszenia satelitów klasy „mikro”.

Dla rakiet wynoszących ładunki na niską orbitę okołoziemską startujących z pewnej wysokości zapewnionej przez transportujący je statek powietrzny możliwe jest zastosowanie dyszy działającej w sposób optymalny. Dysze silników rakietowych projektowane są dla konkretnego ciśnienia otoczenia odpowiadającego pewnej wysokości nad Ziemią. Idealna sytuacja ma miejsce, gdy ciśnienie gazów wylotowych opuszczających dyszę równe jest ciśnieniu otoczenia. Jednak ciśnienie zmienia się wraz z wysokością, a najbardziej znaczące zmiany występują w przedziale troposferycznym, czyli od 0 do około $12 \mathrm{~km}$ nad Ziemią. Rozpatrując lot rakiety startującej z powierzchni Ziemi, zauważyć można, że musi ona pokonać obszar znaczących zmian ciśnienia atmosferycznego. Dysza jest zaprojektowana dla jednej konkretnej wartości ciśnienia otoczenia. Z racji ciągłej zmiany z wysokością oczywiste jest, że przez większość czasu dysza musi pracować w warunkach nieoptymalnych [1]. Istotnym aspektem dla podwyższenia efektywności rakiety jest zminimalizowanie różnicy wysokości pomiędzy skrajnymi punktami jej trajektorii.

Lotniczo-rakietowe systemy posiadają także inne zalety. Obiekt wystrzelony na znacznym pułapie przyspiesza w rozrzedzonej atmosferze, dzięki czemu ciśnienie dynamiczne (zależne od gęstości ośrodka oraz prędkości obiektu) jest mniejsze niż w przypadku startu z naziemnej wyrzutni. Wiąże się to z mniejszymi obciążeniami dynamicznymi, dzięki czemu konstrukcja może być uproszczona, co również może przekładać się na zmniejszenie jej masy.

Oprócz korzyści osiągowych ważne są też korzyści operacyjne. Tego rodzaju systemy nie wymagają budowy specjalnych naziemnych wyrzutni, których konstrukcja pochłania ogromne zasoby finansowe. Funkcję platformy startowej pełni statek powietrzny przenoszacy rakietę. Takie rozwiązanie gwarantuje dużą elastyczność i mobilność, dzięki czemu obiekt może zostać wyniesiony na orbitę o dowolnej inklinacji. Istotna jest także niezależność od warunków pogodowych. Konwencjonalne wystrzelenia wiążą się często z koniecznością przesunięcia startu na inny dzień, ze względu na niesprzyjającą aurę.

Główną wadą użytkowania analizowanych systemów jest ograniczenie wynikające z udźwigu samolotu-nosiciela. Węzły mocowania z reguły zlokalizowane pod skrzydłami lub pod kadłubem mają także swoją ograniczoną wytrzymałość. Dodatkowo maksymalne wymiary geometryczne rakiety również są ograniczone wymiarem samego statku powietrznego czy prześwitem między kadłubem a podłożem w przypadku podwieszeń [1]. W efekcie wymiary i masa wynoszonych obiektów orbitalnych są znacznie ograniczone. Jak już wcześniej wspomniano, mikrosatelity o masie nieprzekraczającej $30 \mathrm{~kg}$ wydają się być najbardziej właściwymi obiektami do transportowania w trybie proponowanego wynoszenia etapowego.

W ciągu ostatnich kilkudziesięciu lat dość krótkiej historii lotnictwa i kosmonautyki rozwijanych było co najmniej kilka programów kosmicznych bazujących na założeniu odstrzeliwania 
rakiety misyjnej z wysokości osiąganej uprzednio przez transportujący ją samolot. Prawdopodobnie pierwszym lotniczo-rakietowym systemem wynoszenia ładunków na orbitę był amerykański projekt Pilot [4]-[6]. Prace nad nim rozpoczęto ze względu na pomyślne umieszczenie Sputnika w przestrzeni kosmicznej przez ZSRR w 1957 r. Testy systemu miały miejsce w 1958 r. Użyta rakieta posiadała mase $950 \mathrm{~kg}$ i mogła wynieść satelitę o masie ok. $1 \mathrm{~kg}$. Oficjalnie jednak żadna z kilku próbnych misji nie zakończyła się sukcesem. Pod koniec lat 70. ubiegłego wieku rozpoczęto w USA prace nad koncepcją broni antysatelitarnej (ASAT). W 1982 przeprowadzono testy pocisku ASM-135, który z założenia miał niszczyć wrogie satelity energią kinetyczną [7], [8]. Samolotem wytypowanym do wynoszenia rakiety był myśliwiec F-15. Przeprowadzono kilka prób systemu, jednakże najbardziej istotna była ta, która zakończyła się demonstracyjnym zniszczeniem sztucznego satelity Solwind P78-1. Przeprowadzenie próby dowiodło, że zestrzelenie potencjalnych satelitów szpiegowskich jest możliwe z wykorzystaniem konwencjonalnego wyposażenia armii. Bardziej spektakularny sukces Amerykanie osiągnęli na przełomie lat 80. i 90. ubiegłego wieku. System Pegasus został zaprezentowany w 1989 r. [9]-[11]. Jest to jeden z najbardziej niezawodnych komercyjnych lotniczo-rakietowych systemów wynoszenia ładunków orbitalnych. Rakiety o masie $18500 \mathrm{~kg}$ (Pegasus) oraz $23000 \mathrm{~kg}$ (Pegasus XL) są przenoszone przez przystosowany do tego samolot pasażerski Lockheed L-1011 Tristar. Masa użyteczna tych rakiet to ok. $440 \mathrm{~kg}$. Dotychczas przeprowadzono 44 misje z wykorzystaniem systemu Pegasus. Schemat realizacji kompletnej misji z uwzględnieniem etapów lotu trójczłonowej rakiety transportującej obiekt satelitarny na odległość przeszło $700 \mathrm{~km}$ od Ziemi zademonstrowano na rys. 1.

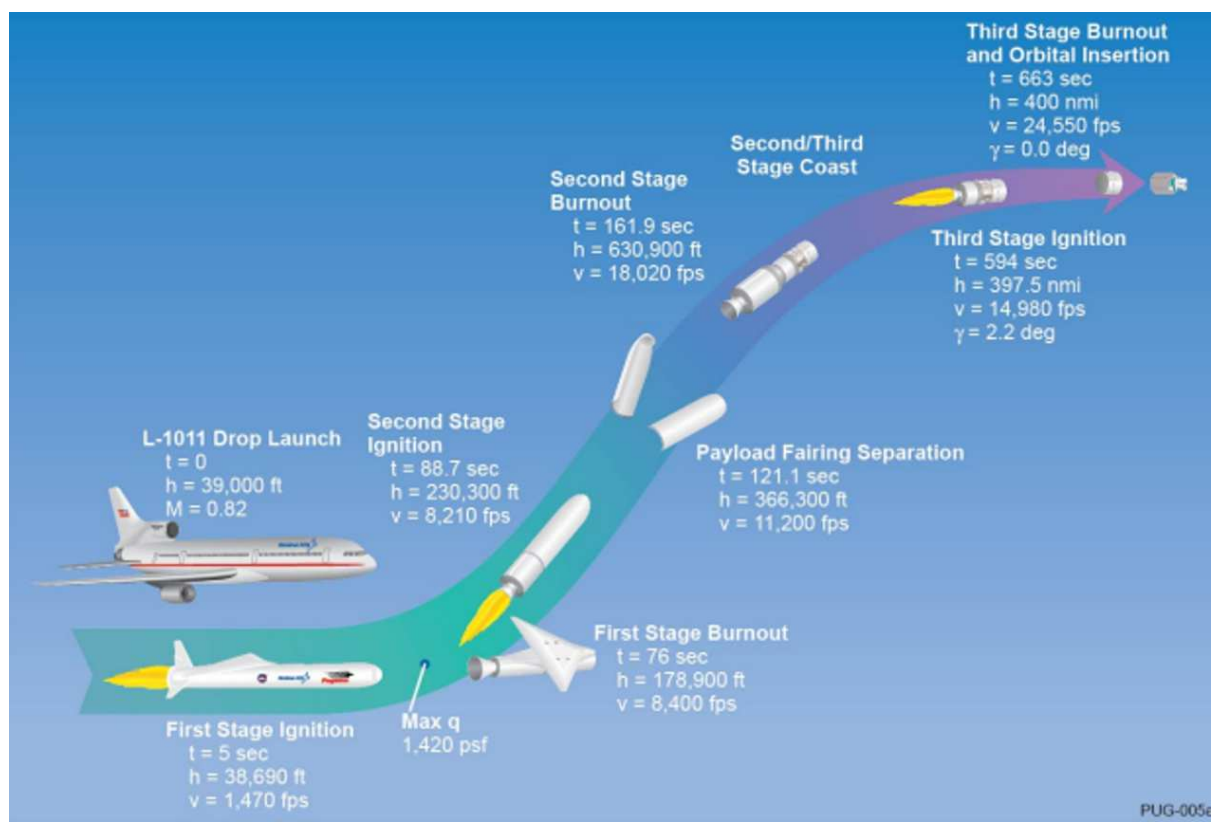

Rys. 1. Schemat etapów realizacji misji wynoszenia trójczłonowej rakiety Pegasus z ładunkiem satelitarnym przez samolot Lockheed L-1011 TriStar [11]

W 2006 roku inżynierowie koncernu Boeing przedstawili koncepcję wykorzystania myśliwca F-15 GSE do przenoszenia dużej rakiety w konfiguracji nawieszenia na kadłub samolotu [12]. Założono zastosowanie trzech ostatnich stopni rakiety Minotaur o łącznej masie niemal $13500 \mathrm{~kg}$, za pomocą której możliwe byłoby umieszczenie na orbicie satelity o masie nawet $270 \mathrm{~kg}$. Prace nad tym przedsięwzięciem pozostają nadal w fazie projektu wstępnego. Koncepcję profilu misyjnego, której założenia stały się inspiracją do opracowania autorskiego programu realizacji misji transportu mikro-satelity, pokazano na rys. 2. 


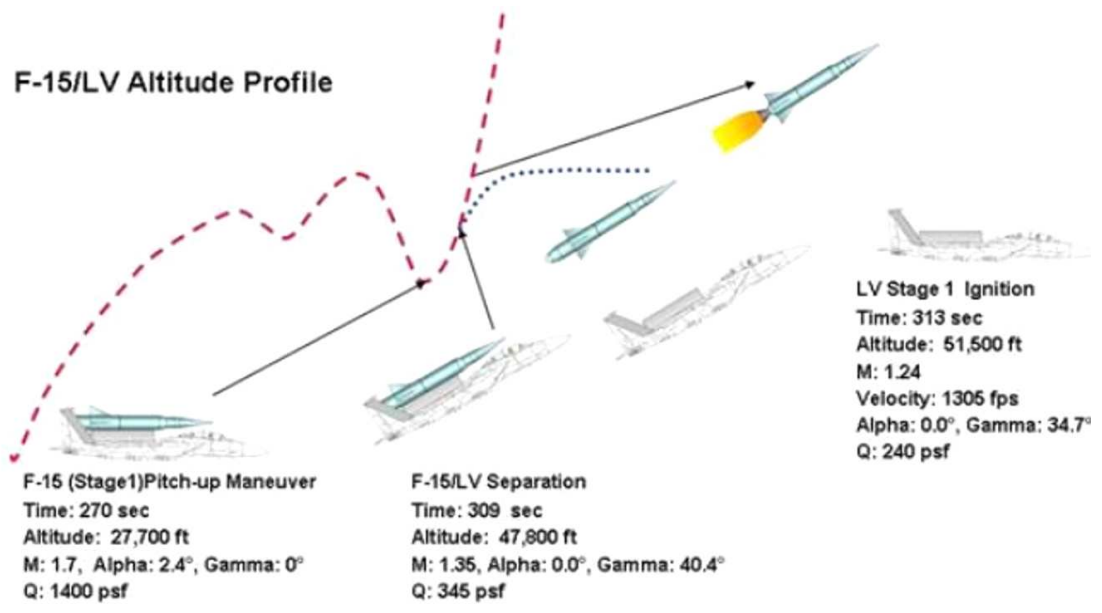

Rys. 2. Koncepcyjny profil misji wyniesienia rakiety transportowej z mini-satelitą nawieszonej na kadłub samolotu F-15 GSE [12]

\section{Wstępne obliczenia masowe dla prognozowanych etapów misji}

Samolot rozważany jako potencjalny nosiciel dla lotniczo-rakietowego systemu wynoszenia obiektów na niską orbitę okołoziemską to eksploatowany przez Siły Powietrzne RP samolot myśliwski MiG-29. Dalsze rozważania opierają się na danych konstrukcyjnych, charakterystykach osiągowych oraz informacjach eksploatacyjnych dostępnych dla tej właśnie konstrukcji. W niniejszej pracy zdecydowano się rozważać opcje rakiety podwieszanej. Odrzucono konfigurację, w której pocisk mocowany jest do węzłów na grzbiecie kadłuba jako wariant eksploatacyjnie niewygodny i bardziej niebezpieczny w locie. Zasadnicze argumenty przemawiające za zastosowaniem konfiguracji z rakietą podwieszaną centralnie na węzłach podkadłubowych to:

- podatność eksploatacyjna,

- łatwość montażu (w przeciwieństwie do rakiety nawieszanej),

- większa szansa uniknięcia poważnych modyfikacji struktury płatowca,

- łatwiejszy do przewidzenia wpływ na stateczność samolotu (czynnik szczególnie istotny w chwili oddzielenia na docelowym pułapie, ale też przez cały czas lotu z ładunkiem).

Metoda wytypowania najbardziej odpowiedniej rakiety transportowej do wyniesienia ładunku satelitarnego bazuje na wyznaczeniu linii trendu parametrów masowych i geometrycznych na podstawie znanych istniejących rakiet i określeniu szacunkowej masy obiektu podwieszanego. Oznacza to, że w omawianej koncepcji lotniczo-rakietowego systemu wynoszenia obiektów na niską orbitę okołoziemską do analizy trajektorii przyjęto hipotetyczny nośnik rakietowy. W przypadku fizycznej realizacji opracowywanej koncepcji wymagane byłyby dodatkowe prace projektowe i konstrukcyjne celem opracowania docelowej rakiety. Ewentualnie wchodzi też $\mathrm{w}$ gre pozyskanie rakiety o wagomiarach najbardziej zbliżonych do proponowanego wariantu projektowego.

Wykorzystując wirtualny model geometrii samolotu MiG-29 opracowany w Instytucie Techniki Lotniczej WML WAT (rys. 3), wytypowano zalecane wymiary podwieszanego obiektu tak, by możliwy był jego montaż ze względu na ograniczenia przestrzenne. Zadecydowano, że maksymalna średnica korpusu podwieszonego tam pocisku może wynieść $0,3 \mathrm{~m}$, biorąc pod uwage rozpiętość stateczników równą dwukrotności średnicy. Ograniczenie to podyktowane jest wymiarem prześwitu między gondolami silnika. Uwzględniono zapas odległości pomiędzy wierzchołkami stabilizatorów rakiety a ściankami gondoli, który gwarantuje rakiecie sprawne opuszczenie przestrzeni, w której jest przenoszona. Przewidziano także pewien dystans między rakietą a węzłami podwieszenia związany z użyciem adaptera, którego dokładne wymiary nie są jeszcze znane na wstępnym etapie rozważań. 


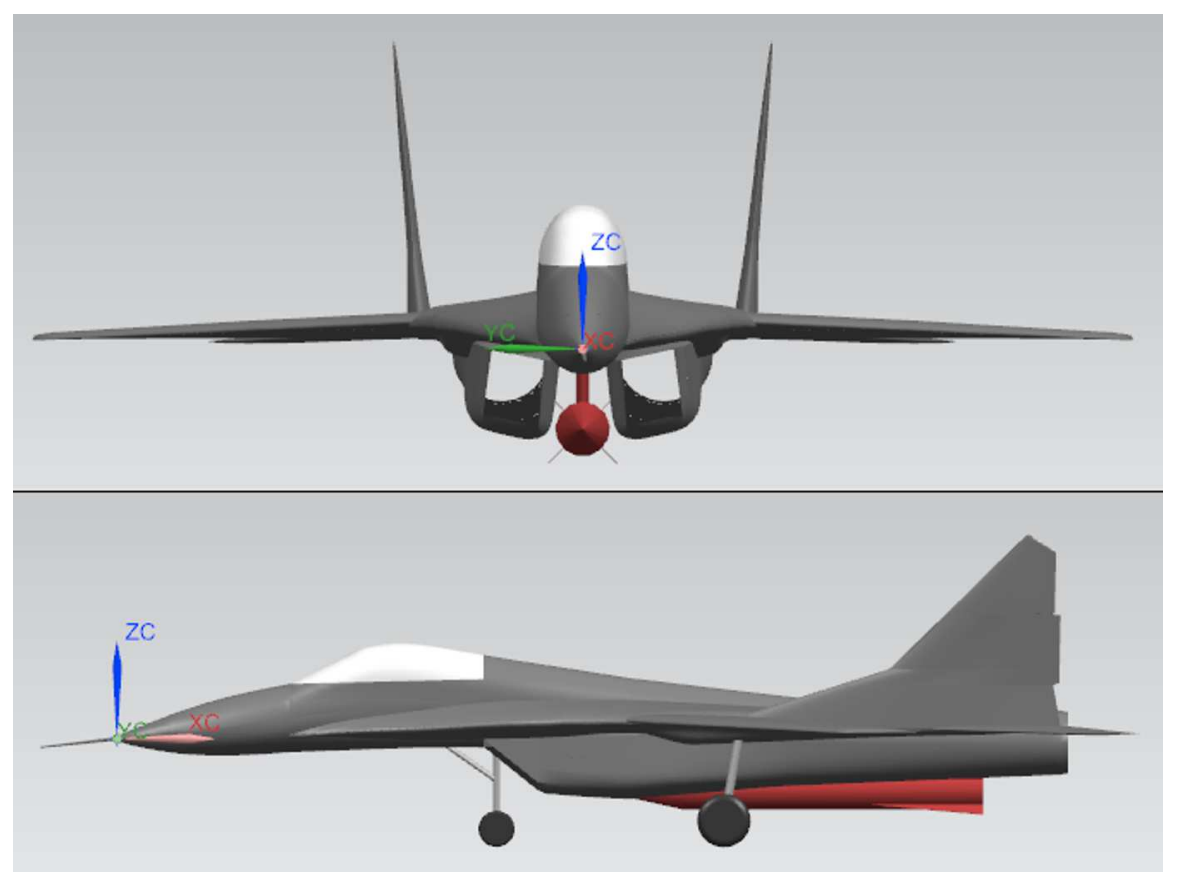

Rys. 3. Model CAD geometrii samolotu MiG-29 z centralnie podwieszoną hipotetyczną rakietą nośną osadzoną na dodatkowym adapterze [30]

Zgromadzone parametry wybranych pocisków rakietowych zaczerpnięte z publikacji [14]-[21] posłużyły do sporządzenia wykresów zależności (rys. 4 i 5): masy rakiet $m_{r}$ w funkcji średnicy przekroju kadłuba $d$ oraz masy rakiet $m_{r}$ w funkcji jej długości $l$. Stosując aproksymację liniową, wyznaczono równania analityczne linii trendowych - dla zależności $m_{r}(d)$ otrzymano $y=2566,8 x-335,17$, natomiast dla zależności $m_{r}(l)$ uzyskano $y=272,01 x-619,26$. Wstawiając ustaloną średnicę $d=0.3 \mathrm{~m}$ do pierwszego równania, otrzymano masę rakiety $434.87 \mathrm{~kg}$. Kładąc za $y \mathrm{w}$ drugim równaniu masę rakiety wyznaczono długość $l=3.88 \mathrm{~m}$.

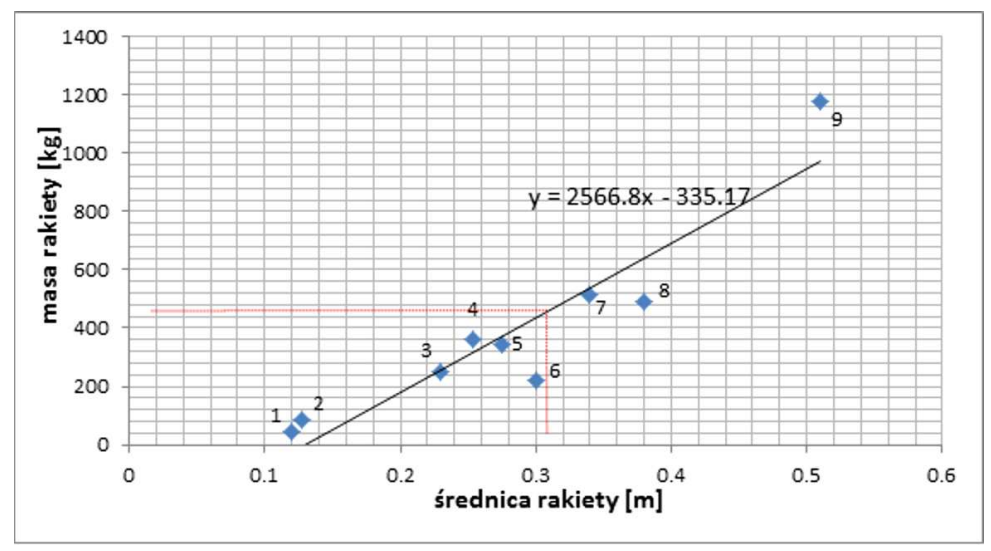

Rys. 4. Wykres aproksymujący trend zależności masy rakiety w funkcji jej średnicy - na podstawie danych masowych i wymiarowych następujących pocisków rakietowych: 1 - R-60, 2 - AIM-9L Sidewinder, 3 - R-27R, 4 - AGM-88 HARM, 5 - Zwiezda Ch-25MŁ,

6 - AGM-65D Maverick, 7 - RGM-84/UGM-84/AGM-84 Harpoon, 8 - R-33, 9 - ASM-135 ASAT

W celu uproszczenia otrzymane wartości zaokrąglono, ostatecznie ustalając mase pocisku rakietowego na $435 \mathrm{~kg}$, a jego długość na $4 \mathrm{~m}$. Zastosowana analiza statystyczna pozwoliła zaprognozować masę rakiety potrzebnej do realizacji koncepcji omawianego systemu. Znając ograniczenia geometryczne odczytane z modelu wirtualnego samolotu MiG-29 oraz posługując się 


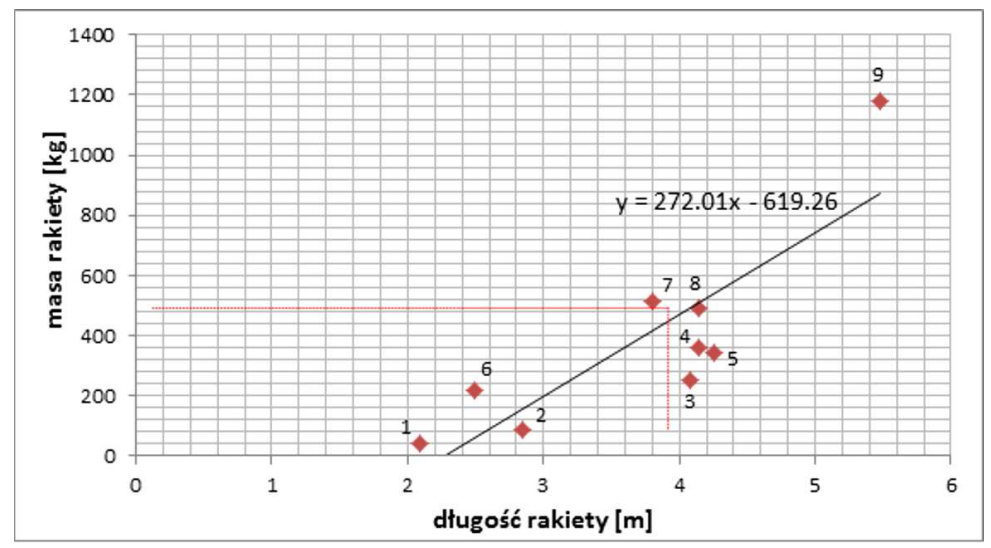

Rys. 5. Wykres aproksymujący trend zależności masy rakiety w funkcji jej długości - na podstawie danych masowych i wymiarowych następujących pocisków rakietowych: 1 - R-60, 2 - AIM-9L Sidewinder, 3 - R-27R, 4 - AGM-88 HARM, 5 - Zwiezda Ch-25MŁ, 6 - AGM-65D Maverick, 7 - RGM-84/UGM-84/AGM-84 Harpoon, 8 - R-33, 9 - ASM-135 ASAT

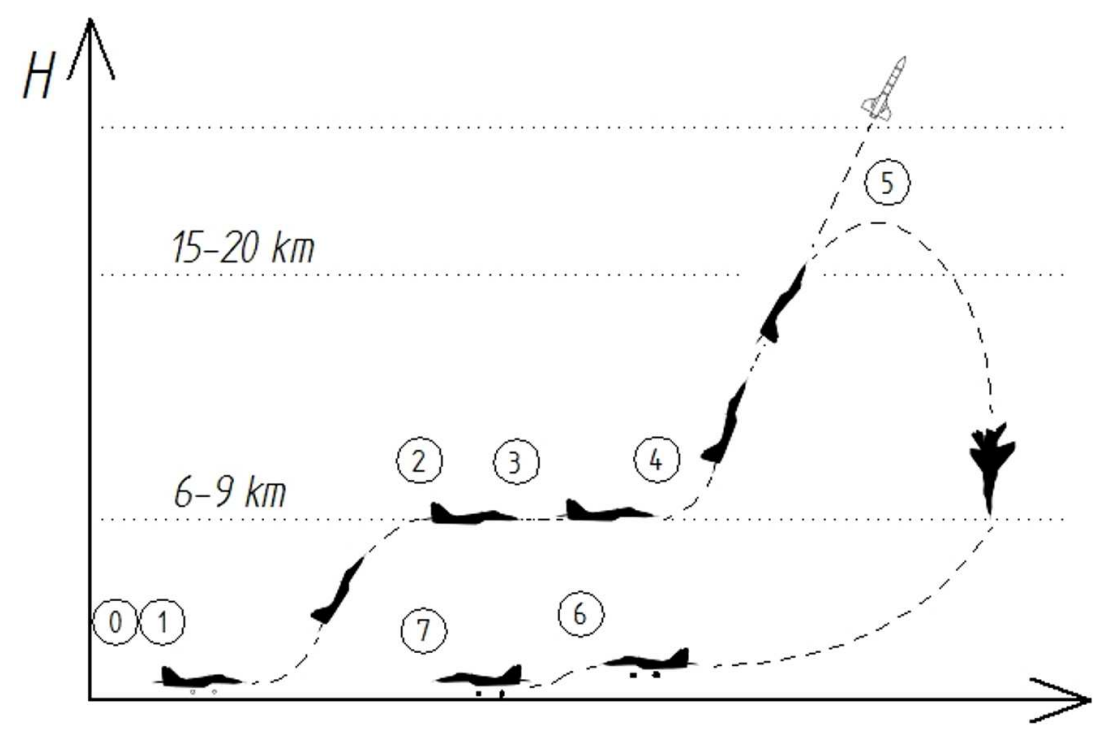

Rys. 6. Profil misji lotniczo-rakietowego zestawu do wyniesienia mikro-satelity na niską orbitę [3]

zależnościami geometryczno-masowymi istniejących rakiet, wyznaczono przewidywaną masę pocisku dla konfiguracji podwieszenia pod kadłubem samolotu. Przyjęto, że misja samolotu MiG-29 z podwieszoną rakietą zawierającą ładunek użyteczny będzie składać się z następujących etapów (rys. 6):

0-1 - uruchomienie silników i kołowanie,

1-2 - start i wznoszenie na zadaną wysokość $H=9000 \mathrm{~m}$,

2-3 - lot poziomy ustalony,

3-4 - rozpędzanie w locie poziomym do prędkości naddźwiękowej odpowiadającej Ma $=1,5$,

4-5 - manewr zoom climb, czyli wznoszenie po torze lotu o kącie nachylenia $60^{\circ}$ do wysokości $13500 \mathrm{~m}$ i odrzucenie rakiety,

5-6 - zniżanie lotem szybowym,

6-7 - zajście do lądowania i lądowanie.

Wymienione wyżej etapy ustalono w oparciu o powstałe już programy wynoszenia ładunków na niską orbitę ziemską za pośrednictwem lotniczo-rakietowych systemów, m.in. projekt wynoszenia rakiety Minotaur przez F-15 GSE. Charakterystyczna część lotu polegająca na rozpędzaniu do naddźwiękowej prędkości, a następnie zamianie energii kinetycznej samolotu na energie poten- 
cjalną wysokości (tzw. zoom climb), to kluczowy etap w fazie transportowania ładunku przez platformę lotniczą.

Obliczenia masowe należy rozpocząć od określenia masy paliwa w chwili rozpoczynania misji. Całkowity zapas paliwa $m_{\text {pal }}$ to masa paliwa zgromadzonego w zbiornikach statku powietrznego, która jest podyktowana eksploatacyjną zużywaną pojemnością paliwa instalacji paliwowej i gęstości paliwa [22]

$$
m_{p a l}=\left(V_{g ł}+V_{P Z P}\right) \rho_{p a l}
$$

gdzie: $V_{g \nmid}$ - eksploatacyjna zużywana pojemność głównej instalacji paliwowej [1], $V_{P Z P}$ - eksploatacyjna zużywana pojemność podwieszanego zbiornika paliwa [1], $\rho_{\text {pal }}$-gęstość paliwa [kg/l].

Eksploatacyjna zużywana pojemność instalacji paliwowej w przypadku samolotów MiG-29 i MiG-29UB wykorzystywanych w Siłach Powietrznych RP wynosi [13], [22], [28]:

- 42001 bez podwieszanego zbiornika paliwa,

- 57001 z podwieszonym dodatkowym zbiornikiem paliwa.

W tabeli 1 przedstawiono zebrane wartości całkowitych zapasów paliwa dla konfiguracji bez podwieszonego zbiornika paliwa i ze zbiornikiem przeliczonych dla gęstości paliwa zawartych w przedziale $0,755 \div 0,845 \mathrm{~kg} / \mathrm{l}$, która jest parametrem zależnym od temperatury. Do obliczeń wybrano średnią wartość gęstości $\rho_{p a l}=0,8 \mathrm{~kg} / \mathrm{m}^{3}$. Samolot MiG-29 wykorzystany do misji nie ma podwieszanego zbiornika paliwa, więc korzystając z równania (2.1), otrzymuje się następującą całkowita mase paliwa [22]: $m_{\text {pal }}=(4200+0) 0,8=3360 \mathrm{~kg}$.

Tabela 1. Całkowite zapasy paliwa na samolotach MiG-29 i MiG-29UB podane w [kg] [22]

\begin{tabular}{|l|c|c|c|c|c|c|c|c|c|c|}
\hline Wariant napeł- & \multicolumn{6}{|c|}{ Gęstość paliwa $\rho_{\text {pal }}[\mathrm{kg} / \mathrm{l}]$ (wartości zależne od temperatury) } \\
\cline { 2 - 11 } nienia paliwem & 0,755 & 0,765 & 0,775 & 0,785 & 0,795 & 0,805 & 0,815 & 0,825 & 0,835 & 0,845 \\
\hline \hline $\begin{array}{l}\text { Zbiorniki inte- } \\
\text { gralne }\end{array}$ & 3170 & 3215 & 3255 & 3300 & 3340 & 3380 & 3425 & 3465 & 3510 & 3550 \\
\hline $\begin{array}{l}\text { zbiorniki inte- } \\
\text { gralne + zb. } \\
\text { podwieszany }\end{array}$ & 4300 & 4360 & 4415 & 4475 & 4530 & 4590 & 4645 & 4705 & 4760 & 4820 \\
\hline
\end{tabular}

Masa samolotu przed startem $m_{0}$ to masa załadowanego samolotu, z napełnioną instalacją paliwową, wyposażonego adekwatnie do celu misji, znajdującego się na płaszczyźnie postojowej lotniska, gotowego na uruchomienie zespołów napędowych, kołowanie i start. Jest ona określana poniższym wzorem [22]

$$
m_{0}=m_{z a \uparrow}+m_{p a l}+m_{p . z e w}
$$

gdzie: $m_{z a \nmid}$ - masa samolotu gotowego do misji [kg]; składa się ona z masy pustego samolotu, załogi z wyposażeniem, eksploatacyjnego wyposażenia, płynów roboczych (olejów, gazów), a także zalegającej części paliwa; wartości dla dwóch rodzajów samolotu podano w tabeli $2, m_{\text {pal }}-$ masa rozporządzalnej części paliwa [kg], obliczona ze wzoru (2.1), $m_{\text {p.zew }}$ - masa podwieszeń zewnętrznych $[\mathrm{kg}]$ - w analizowanym przypadku $435 \mathrm{~kg}$.

Tabela 2. Masy załadowanych samolotów MiG-29 oraz MiG-29UB, wg publikacji [13], [22], [28]

\begin{tabular}{|c|l|c|}
\hline Lp. & \multicolumn{1}{|c|}{ Samolot } & Masa [kg] \\
\hline \hline 1 & MiG-29 & 11175 \\
\hline 2 & MiG-29UB & 11065 \\
\hline
\end{tabular}


Zakłada się, że w misji wykorzystany zostaje samolot MiG-29UB ze względu na nieco mniejszą masę od wersji podstawowej MiG-29 [22]. Podwieszenie stanowi rakieta, której masę ustalono w poprzednim rozdziale. Do obliczeń przyjęto następujące dane masowe:

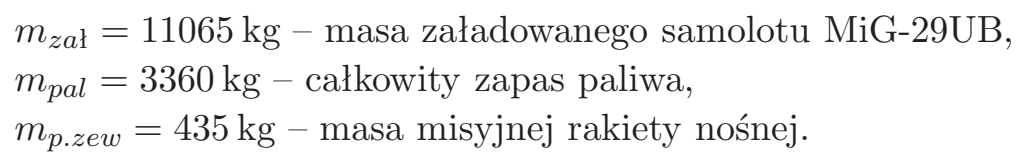

Korzystając z zależności (2.2), określono masę startową samolotu - parametr, który umożliwia dalsze kalkulacje profilu misji: $m_{0}=11065+3360+435=14860 \mathrm{~kg}$.

Następnie przeprowadzono obliczenia zużycia paliwa w poszczególnych etapach misji. Skorzystano przy tym z wykresów zliczania zużycia paliwa podczas lotu zamieszczonych $\mathrm{w}$ instrukcji "Samoloty MiG-29 i MiG-29UB z silnikami RD-33. Obliczanie zasięgu i długotrwałości lotu" [22], przy czym fazy startu i wznoszenia potraktowano jako jeden etap (1-2).

\section{Etap 0-1 - Uruchomienie silników i kołowanie}

Parametr $m_{0-1}$, czyli zużycie paliwa, kiedy samolot jest nadal na ziemi obejmuje masę paliwa zużytego podczas rozruchu zespołu napędowego samolotu i jego próbę na płaszczyźnie postojowej lotniska, masę paliwa zużytego na kołowanie oraz mase paliwa zużytego na kołowanie z drogi startowej na płaszczyznę postojową. Określa się go ze wzoru [22]

$$
m_{0-1}=C_{0-1} t_{0-1}
$$

gdzie: $C_{0-1}$ - uśrednione minutowe zużycie paliwa na ziemi równe $20 \mathrm{~kg} / \mathrm{min}, t_{0-1}$ - czas pracy silników do chwili rozpoczęcia startu.

Zakłada się czas uruchomienia i próby silników oraz kołowania samolotu na próg drogi startowej $t_{0-1}=10 \mathrm{~min}$. Ze wzoru (2.3) wówczas otrzymuje się $m_{0-1}=200 \mathrm{~kg}$.

Wyjściowym parametrem jest masa samolotu w momencie rozpoczęcia startu $m_{1}$, która stanowi daną wejściową obliczeń kolejnego etapu misji [22]

$$
m_{1}=m_{0}-m_{0-1}
$$

Ostateczny wynik to $m_{1}=14860-200=14660 \mathrm{~kg}$.

\section{Etap 1-2 - Start i wznoszenie}

Zakłada się wznoszenie na wysokość $H=9000 \mathrm{~m}$. Kalkulacje przeprowadzono na podstawie wykresu przedstawiającego dane dla połączonych etapów startu i wznoszenia samolotu MiG-29 na wybraną wysokość, toteż dokonano zespolenia etapów misji. Start na maksymalnym zakresie pracy silników (bez dopalania) odbywa się do osiągnięcia prędkości $V_{p}=300 \mathrm{~km} / \mathrm{h}$. Samolot rozpoczyna wznoszenie z jednoczesnym rozpędzaniem, osiągając prędkość $V_{r}=850 \mathrm{~km} / \mathrm{h}$ do pułapu $H=1000 \mathrm{~m}$. Wznoszenie na ustaloną wysokość $H=9000 \mathrm{~m}$ musi odbywać się z zachowaniem prędkości $V_{r}$ [22]. Ustalenia te umożliwiają oszacowanie zużycia paliwa, przebytej drogi i czasu lotu na podstawie pomocniczych wykresów praktycznych zasięgów i długotrwałości lotu zawartych w opracowaniu Dowództwa Wojsk Lotniczych i Obrony Powietrznej. By skorzystać $\mathrm{z}$ charakterystyk lotu przedstawionych w wymienionym wydawnictwie, trzeba określić sumaryczny wskaźnik przeliczeniowy współczynnika oporu czołowego [22]

$$
\sum W O C=W O C_{z a \uparrow}+W O C_{p . z e w}
$$

gdzie: $W O C_{z a ł}$ - współczynnik oporu czołowego załadowanego samolotu bez podwieszeń, $W O C_{\text {p.zew }}$ - współczynnik oporu czołowego zewnętrznych podwieszeń. 
Współczynniki oporu czołowego dla samolotu MiG-29, MiG-29UB oraz dla wybranych rodzajów podwieszanego uzbrojenia zawarte są w tabeli 3. Dla samolotu MiG-29UB jest to $W O C=230$, natomiast współczynnik oporu czołowego dla pocisku rakietowego przewiduje się na poziomie $W O C=15$, biorąc pod uwagę wartości tego współczynnika dla pocisków rakietowych zebranych w tabeli. Sumaryczna wartość $W O C$ wg wzoru (2.5) ostatecznie wynosi: $\sum W O C=230+15=245$.

Tabela 3. Wskaźniki WOC samolotów MiG-29, MiG-29UB oraz wybranych podwieszeń wg [22]

\begin{tabular}{|c|l|c|c|}
\hline Lp. & \multicolumn{1}{|c|}{ Rodzaj obiektu } & Liczba & WOC \\
\hline \hline 1 & WOC samolotu MiG-29 i MiG-29UB & - & 230 \\
\hline 2 & WOC podwieszanego zbiornika paliwa PTB-1500 & 1 & 22 \\
\hline 3 & Wyrzutnie APU-27 & 2 & 7 \\
\hline 4 & Belki nośne BD3-UMK-2A & 2 & 20 \\
\hline 5 & Niekierowane pociski rakietowe S-24B & 2 & 43 \\
\hline 6 & Kierowane pociski rakietowe R-27R1 & 2 & 17 \\
\hline 7 & Kierowane pociski rakietowe R-73E & 2 & 12 \\
\hline 8 & Wyrzutnie B8-M1 & 2 & 50 \\
\hline 9 & Bomba FAB-500SzN & 2 & 65 \\
\hline 10 & Bomba P-50-75 & 2 & 15 \\
\hline 11 & Bomba ZAB-500Sz & 2 & 110 \\
\hline
\end{tabular}

Znajomość masy samolotu do startu, współczynnika oporu czołowego oraz nakazanego pułapu pozwoliły na wyznaczenie masy zużytego paliwa, posługując się odpowiednim wykresem (Wykres do określania zużycia paliwa podczas startu i lotu wznoszacego do nakazanej wysokości zamieszczony w [32]). Wyliczono, że etap startu na maksymalnym zakresie pracy silników i wznoszenie na wysokość $H=9000 \mathrm{~m}$ z uwzględnieniem wcześniej wymienionych warunków pochłonie mase paliwa $m_{1-2}=365 \mathrm{~kg}$. Tak więc masa samolotu w chwili osiągnięcia wymaganego pułapu jest równa

$$
m_{2}=m_{1}-m_{1-2}
$$

Ostateczny wynik: $m_{2}=14660-365=14295 \mathrm{~kg}$.

Charakterystyki z Wykresu do określania czasu i drogi podczas lotu wznoszacego na nakazana wysokość [32] pozwoliły także na określenie czasu wznoszenia równego około $t_{1-2}=3 \min 30 \mathrm{~s}$ oraz droge przebytą przez samolot w czasie wznoszenia $S_{1-2}=40 \mathrm{~km}$.

\section{Etap 2-3 - Poziomy lot ustalony}

Etap ten obejmuje poziomy lot ustalony z prędkością $V_{H}=850 \mathrm{~km} / \mathrm{h}(236,11 \mathrm{~m} / \mathrm{s})$ na wysokości $H=9000 \mathrm{~m}$, podczas którego samolot pokonuje drogę $S_{2-3}=25 \mathrm{~km}$. Aby odczytać poszukiwane parametry z wykresów, niezbędne jest określenie liczby Macha wg wzoru [23]

$$
\mathrm{Ma}=\frac{V_{H}}{\sqrt{k R T_{H}}}
$$

gdzie $V_{H}$ - prędkość lotu $[\mathrm{m} / \mathrm{s}], k$ - wykładnik przemiany izentropowej równy $1,4, R$ - stała gazowa dla powietrza równa $287[\mathrm{~J} /(\mathrm{kgK})]$.

Temperaturę na danej wysokości (do pułapu 11 km) można obliczyć ze wzoru [24]

$$
T_{H}=T_{0}-\left(6,5 \frac{\mathrm{K}}{\mathrm{km}} H\right)
$$


gdzie: $T_{0}$ - temperatura powietrza na wysokości $H=0 \mathrm{~km}$ wg ISA wynosząca $288,15 \mathrm{~K}$, $H$ - wysokość nad ziemią [km].

Otrzymuje się

$$
T_{H}=288,15-(6,5 \cdot 9)=229,65 \mathrm{~K} \quad \mathrm{Ma}=\frac{236,11}{\sqrt{(1,4 \cdot 287 \cdot 229, ! 65}}=0,77
$$

Z charakterystyki: Wykres służący do określania wspótczynnika kilometrowego zużycia paliwa na zakresach pracy silników bez dopalania zamieszczonym w [32] odczytano współczynnik kilometrowego zużycia paliwa, posiłkując się liczbą Macha, masą samolotu oraz pułapem. Wyniósł on $W K Z P=25$. Korzystając z charakterystyki Wykres stużacy do określania kilometrowego zużycia paliwa przy pracy silników na zakresach bez dopalania w zależności od wspótczynnika kilometrowego zużycia paliwa zam. w [32] oraz ustalonej wartości współczynnika, wyznaczono kilometrowe zużycie paliwa $C_{2-3}=2,2 \mathrm{~kg} / \mathrm{km}$. Masa paliwa spalonego w ustalonym locie poziomym to $\mathrm{wg}$ $[22]$

$$
m_{2-3}=S_{2-3} C_{2-3}
$$

Uzyskana wartość: $m_{2-3}=25 \cdot 2,2=55 \mathrm{~kg}$. Czas ustalonego lotu poziomego określić można za pomocą wzoru

$$
t_{2-3}=\frac{S_{2-3}}{V_{H}}
$$

Uzyskana wartość: $t_{2-3}=25000 / 236,11=106 \mathrm{~s}=1 \min 46 \mathrm{~s}$.

Masa samolotu pod koniec ustalonego lotu poziomego jest wg [22] określana wzorem

$$
m_{3}=m_{2}-m_{2-3}
$$

Ostateczny wynik: $m_{3}=14295-55=14240 \mathrm{~kg}$.

\section{Etap 3-4 - Rozpędzanie w locie poziomym}

Zużycie paliwa $m_{3-4}$, przebytą odległość $S_{3-4}$ oraz czas rozpędzania $t_{3-4} \mathrm{w}$ locie poziomym z silnikami pracującymi na zakresie pełnego dopalania na pułapie $H=9000 \mathrm{~m}$ określono za pomocą charakterystyki Wykres do określania zużycia paliwa, drogi i czasu rozpędzania samolotu w locie prostoliniowym na wysokości $9000 \mathrm{~m}$ na zakresie pracy silników z petnym dopalaniem zam. w [32]. Na początku odczytano wartości następujących parametrów dla Ma $=0,77: m_{3-4_{1}}=$ $100 \mathrm{~kg}, S_{3-4_{1}}=5 \mathrm{~km}, t_{3-4_{1}}=30 \mathrm{~s}$. Następnie odczytano wartości dla Ma $=1,5: m_{3-4_{2}}=480 \mathrm{~kg}$, $S_{3-4_{2}}=24 \mathrm{~km}, t_{3-4_{2}}=94 \mathrm{~s}$. Parametry obliczane dla rozpędzania od Ma $=0,77$ do Ma $=1,5$ są określone w [22] następującymi formułami różnicowymi

$$
m_{3-4}=m_{3-4_{2}}-m_{3-4_{1}} \quad S_{3-4}=S_{3-4_{2}}-S_{3-4_{1}} \quad t_{3-4}=t_{3-4_{2}}-t_{3-4_{1}}
$$

Podstawiając dane, obliczono zużycie paliwa, drogę, oraz czas rozpędzania samolotu MiG-29 na zadanym pułapie, czyli kolejno: $m_{3-4}=480-100=380 \mathrm{~kg}, S_{3-4}=24-5=19 \mathrm{~km}$, $t_{3-4}=94-30=64 \mathrm{~s}=1 \min 4 \mathrm{~s}$. Tak więc masa samolotu $\mathrm{w}$ chwili osiągnięcia prędkości $\mathrm{Ma}=1,5 \mathrm{wg}[22]$ jest równa

$$
m_{4}=m_{3}-m_{3-4}
$$

Ostateczny wynik przy prędkości Ma $=1,5: m_{4}=14240-380=13860 \mathrm{~kg}$. 


\section{Etap 4-5 - Manewr zoom climb $i$ odrzucenie rakiety}

Z chwilą uzyskania naddźwiękowej prędkości wyrażonej liczbą Ma $=1,5$, pilot przyciąga drążek sterowy do siebie, wprowadzając samolot w lot wznoszący po torze o nachyleniu $\gamma=60^{\circ}$, jednocześnie ustawiając zakres pracy silników na bieg jałowy. Wznoszenie się samolotu ze stopniowym wytracaniem prędkości można uprościć do zagadnienia rzutu ukośnego. Temperatura na pułapie $H=9000 \mathrm{~m}$ wynosi $T_{H}=229,65 \mathrm{~K}$, a więc korzystając z przekształconego wzoru (2.7) na liczbę Macha można wyznaczyć prędkość: $V_{H}=1,5 \sqrt{1,4 \cdot 287 \cdot 229,65}=455,65 \mathrm{~m} / \mathrm{s}$. Wysokość maksymalną, na jaką może wznieść się ciało - w tym przypadku samolot MiG-29 jest dana znanym w literaturze wzorem [25], [26]

$$
H_{\max }=H+\frac{\left(V_{0} \sin \alpha\right)^{2}}{2 g}
$$

gdzie: $H$ - pułap lotu obiektu misyjnego [m], $V_{0}$ - prędkość początkowa obiektu misyjnego, w tym przypadku $V_{H}[\mathrm{~m} / \mathrm{s}], \alpha$ - kąt pochylenia toru lotu $\left[{ }^{\circ}\right], g$ - przyspieszenie ziemskie. Podstawiając dane, otrzymuje się: $H_{\max }=9000+\left(455,65 \sin 60^{\circ}\right)^{2} /(2 \cdot 9,81)=16936,4 \mathrm{~m}$. Jest to maksymalny pułap obliczeniowy, jaki osiągnie samolot podczas stromego wznoszenia z jednoczesnym wytracaniem prędkości. Rzeczywista wartość tego pułapu jest zapewne niższa, gdyż równanie (2.14) nie uwzględnia oporów aerodynamicznych. Ponadto, osiągając obliczoną wysokość, samolot miałby prędkość $V_{H}=0$, co oznacza brak możliwości sterowania statkiem powietrznym. Aby zapewnić manewrowość, maksymalną wysokość na potrzeby misji ustala się na poziomie $H_{\max }=13500 \mathrm{~m}$. Samolot ma więc do pokonania różnicę wysokości: $\Delta H=H_{\max }-H=13500-9000=4500 \mathrm{~m}$. Chwilową wysokość, na jakiej po czasie $t$ znajduje się MiG-29 podczas wznoszenia, można wyrazić wzorem wg [25], [26]

$$
y=\left(V_{0} \sin \alpha\right) t-\frac{g t^{2}}{2}
$$

Aby obliczyć czas, po jakim samolot osiągnie pułap $H=13500 \mathrm{~m}$, na którym następuje odłączenie rakiety, podstawia się dane, przy czym $y=\Delta H: 4500=\left(455,65 \sin 60^{\circ}\right) t-\left(9,81 t^{2}\right) / 2$.

Równanie kwadratowe wyznaczone na podstawie wzoru (2.15) ma postać: $-4,905 t^{2}+394,6 t-$ $4500=0$. Rozwiązaniem będą dwie wartości czasu, odpowiadające punktom przecięcia się ramion paraboli z poziomą prostą wykreśloną dla $y=\Delta H=4500$. Wyznaczone rozwiązania to:

$$
t_{p} 1=\frac{-394,6+\sqrt{67419,16}}{2 \cdot(-4,905)}=13,75 \mathrm{~s} \quad t_{p 2}=\frac{-394,6-\sqrt{67419,16}}{2 \cdot(-4,905)}=66,70 \mathrm{~s}
$$

Czas wznoszenia samolotu w sposób zbliżony do obiektu w rzucie ukośnym na wysokość $H=13500 \mathrm{~m}$ z pułapu $H=9000 \mathrm{~m}$, wynosi więc $t_{4-5}=13,75 \mathrm{~s}$. Poprawność kalkulacji można sprawdzić, wyznaczając całkowity czas lotu ciała w rzucie ukośnym aż do upadku do początkowej wysokości, dla zadanej prędkości początkowej oraz kąta rzutu wg [25], [26]

$$
t_{c}=\frac{2 V_{0} \sin \alpha}{g}
$$

Wyliczona $\mathrm{w}$ ten sposób wartość to $t_{c}=80,45 \mathrm{~s}$. Lot rzuconego ciała do momentu osiągnięcia maksymalnej wysokości zajmuje tyle samo czasu, co droga powrotna do początkowej wysokości. Odejmując od całkowitego czasu $t_{c}$ czas lotu $t_{p 1}=t_{4-5}$ do pułapu $H=13500 \mathrm{~m}$, powinno się więc otrzymać czas $t_{p 2}: t_{c}-t_{p 1}=80,45-13,75=66,70 \mathrm{~s}$. Wynik ten potwierdza poprawność poprowadzonych obliczeń.

Chwilę przed osiągnięciem pułapu $H=13500 \mathrm{~m}$, następuje odrzucenie pocisku rakietowego. Droga przebyta przez samolot w czasie tego manewru została określona z własności trygonometrycznych i wynosi $S_{4-5}=5,2 \mathrm{~km}$. Ze względu na pracę silników na zakresie biegu jałowego 
i dodatkowo na dużych wysokościach niewielkie zużycie paliwa podczas omawianego etapu lotu założono na poziomie $m_{4-5}=10 \mathrm{~kg}$. Czas trwania tego segmentu lotu $t_{4-5}=13,75 \approx 14 \mathrm{~s}$. Masa w chwili ukończenia lotu na tym etapie jest wyliczana wzorem

$$
m_{5}=m_{4}-m_{4-5}-m_{p . z e w}
$$

Zatem ostateczny wynik: $m_{5}=13860-10-435=13415 \mathrm{~kg}$.

\section{Etap 5-6 - Zniżanie}

Zniżanie z wysokości $H=13500 \mathrm{~m}$ może być realizowane lotem szybowym z utrzymaniem prędkości przyrządowej $V_{p}=500 \mathrm{~km} / \mathrm{h}$, a silniki pracują na zakresie biegu jałowego [22]. Zachowanie tych warunków umożliwia odczyt poszukiwanych parametrów z charakterystyk zniżania samolotu MiG-29. Posługując się charakterystyką: Wykres do określania drogi, zużycia paliwa i czasu lotu szybowego na zakresie biegu jałowego dla wszystkich wartości wspótczynnika oporu czołowego samolotu zam. w [32], odczytano: zużycie paliwa $m_{5-6}=120 \mathrm{~kg}$, przebytą drogę $S_{5-6}=112 \mathrm{~km}$ oraz czas zniżania $t_{5-6}=9 \mathrm{~min}$. Masę samolotu na końcu etapu zniżania można wyznaczyć wzorem [22]

$$
m_{6}=m_{5}-m_{5-6}
$$

Zatem ostateczny wynik: $m_{6}=13415-120=13295 \mathrm{~kg}$

\section{Etap 6-7 - Zajście do lqdowania i lqdowanie}

Masę zużytego paliwa podczas manewru podejścia do lądowania i samego lądowania określa się ze wzoru [22]

$$
m_{6-7}=C_{6-7} t_{6-7}
$$

gdzie: $C_{6-7}$ - średnie minutowe zużycie paliwa podczas lotu po kręgu w pobliżu lotniska wraz z lądowaniem, wynosi $50 \mathrm{~kg} / \mathrm{min}$ [22], $t_{6-7}$ - czas zajścia i manewr lądowanie, przyjęto $10 \mathrm{~min}$. Po podstawieniu danych otrzymuje się: $m_{6-7}=50 \cdot 10=500 \mathrm{~kg}$. Masa samolotu MiG-29 po wylądowaniu jest więc równa [22]

$$
m_{7}=m_{6}-m_{6-7}
$$

Ostatecznie masa samolotu po wylądowaniu wynosi: $m_{7}=13295-500=12795 \mathrm{~kg}$.

Samolot MiG-29 rozpoczyna misje ze zbiornikami zatankowanymi do pełna - łączna masa paliwa przed uruchomieniem silników i kołowaniem według danych taktyczno-technicznych publikowanych w poz. [13] powinna wynosić $3360 \mathrm{~kg}$. Po wykonaniu misji o wybranym profilu w zbiornikach samolotu znajduje się $1730 \mathrm{~kg}$ paliwa (tabela 4). Z obliczeń wynika więc, że zużyte zostało $1630 \mathrm{~kg}$ nafty lotniczej, co stanowi tylko $49 \%$ początkowej masy paliwa znajdującego się w zbiornikach. Oznacza to, że profil misji może ulec modyfikacji - pozostałe w zbiornikach paliwo pozwoliłoby choćby na zwiększenie zasięgu misji, jeśli istniałaby konieczność oddalenia się na większą odległość od lotniska. Możliwe byłoby także zastosowanie znacznie cięższej, a co za tym idzie większej rakiety niż ta wzięta pod uwage w niniejszych rozważaniach. Całkowity czas realizacji założonego zadania od chwili uruchomienia silników do lądowania wynosi ponad 35 minut, a przebyta przez samolot odległość według wstępnych obliczeń została oszacowana na około $200 \mathrm{~km}$. 
Tabela 4. Wartości mas obiektu misyjnego oraz paliwa na koniec każdego etapu misji

\begin{tabular}{|c|c|c|c|c|}
\hline \multirow{2}{*}{ Lp. } & \multirow{2}{*}{ Etap misji } & \multicolumn{3}{|c|}{ Masa na koniec danego etapu misji [kg] } \\
\cline { 3 - 5 } & & Obiekt misyjny & $\begin{array}{c}\text { Paliwo } \\
\text { zbiornikach }\end{array}$ & $\begin{array}{c}\text { Paliwo zużyte } \\
\text { w etapie lotu }\end{array}$ \\
\hline \hline- & Załadowany samolot & 14860 & 3360 & - \\
\hline 1 & $0-1$ & 14660 & 3160 & 200 \\
\hline 2 & $1-2$ & 14295 & 2795 & 365 \\
\hline 3 & $2-3$ & 14240 & 2740 & 55 \\
\hline 4 & $3-4$ & 13860 & 2360 & 380 \\
\hline 5 & $4-5$ & 13415 & 2350 & 10 \\
\hline 6 & $5-6$ & 13295 & 2230 & 120 \\
\hline 7 & $6-7$ & 12795 & 1730 & 500 \\
\hline \multicolumn{5}{r}{} \\
\cline { 3 - 5 }
\end{tabular}

Tabela 5. Czasy trwania kolejnych etapów misji oraz pokonane przez samolot etapowe odległości

\begin{tabular}{|c|c|c|c|}
\hline Lp. & Etap misji & $\begin{array}{c}\text { Czas trwania etapu } \\
\Delta t_{i-(i+1)}[\mathrm{s}]\end{array}$ & $\begin{array}{c}\text { Przebyta odległość } \\
\text { w etapie } s_{i-(i+1)}[\mathrm{km}]\end{array}$ \\
\hline \hline 1 & $0-1$ & 600 & - \\
\hline 2 & $1-2$ & 210 & 40 \\
\hline 3 & $2-3$ & 106 & 25 \\
\hline 4 & $3-4$ & 64 & 19 \\
\hline 5 & $4-5$ & 14 & 5,2 \\
\hline 6 & $5-6$ & 540 & 112 \\
\hline 7 & $6-7$ & 600 & - \\
\hline & Suma & 2134 & 201,2 \\
\cline { 2 - 4 }
\end{tabular}

\section{Przygotowanie danych obliczeniowych do programu APP}

Projekt na aktualnym etapie realizacji jest zaledwie koncepcją. Analizy prowadzone w ramach tzw. studium realizowalności przedsięwzięcia mają na razie znaczenie tylko teoretyczne, ale uzyskane wyniki będą determinować ewentualną strategię ustalania poczynań w ramach szczegółowego projektowania, dedykowanych technologii i harmonogramu realizacji misji. Do obliczeń profilu misyjnego wzięto dane dotyczące hipotetycznej, nieistniejącej w rzeczywistości rakiety, której parametry geometryczne i masowe ustalono poprzez analizę trendów dla wybranej grupy podwieszanych pocisków rakietowych. W celu ułatwienia potencjalnej implementacji systemu w przyszłości, do dalszych rozważań założono zastosowanie rakiety skonstruowanej i zbudowanej w Polsce. Wytypowano rakietę ILR-33 Bursztyn zaprojektowaną i zbudowaną w Instytucie Lotnictwa w Warszawie [27]. Rakieta będąca aktualnie w fazie rozwojowej z założenia jest konstrukcją eksperymentalną, jednak w miarę rozwoju projektu mogłaby sprostać wymaganiom komercyjnego sektora kosmicznego. Korpus ma średnicę $23 \mathrm{~cm}$, natomiast cała konstrukcja mierzy $5 \mathrm{~m}$ długości. Według autorów projektu rakieta ostatecznie będzie w stanie wynieść ładunek satelitarny o masie około $10 \mathrm{~kg}$ nawet do tzw. linii Karmana (pułap wynoszący $100 \mathrm{~km}$, gdzie mogą operować nano- i mikrosatelity).

Na potrzeby dalszych obliczeń opracowano uproszczony model geometryczny CAD rakiety w systemie Siemens NX. Wymiary gabarytowe i masę określono w sposób przybliżony w trybie analizy danych publikacyjnych.

Masę rakiety, której podstawowe wymiary podano na rys. 7, oszacowano ostatecznie na $247 \mathrm{~kg}$. Pocisk ten jest więc lżejszy o $188 \mathrm{~kg}$ od pocisku rakietowego, którego parametry zostały 


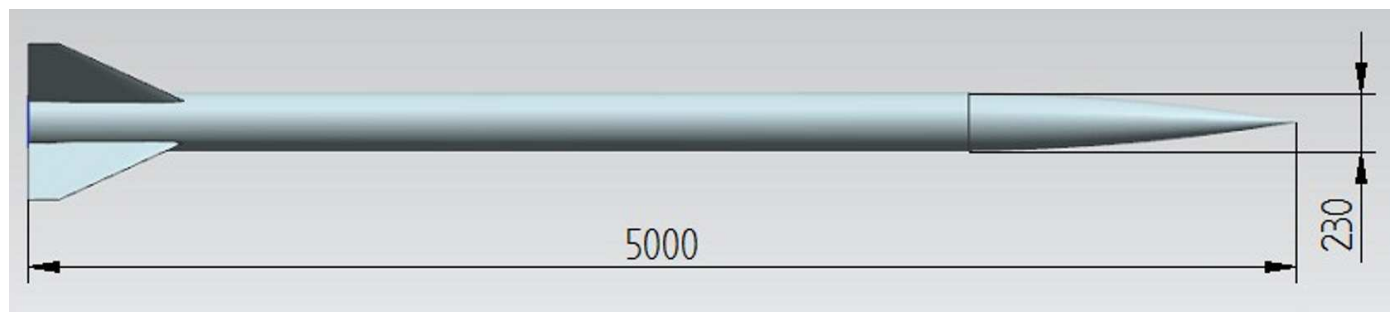

Rys. 7. Uproszczony model bryłowy rakiety ILR-33 Bursztyn z orientacyjnie ustalonymi wymiarami

wstępnie wyznaczone w oparciu o charakterystyki trendowe z rysunków 4 i 5. Szacowana maksymalna masa satelity, który mógłby zostać wyniesiony na niską orbitę okołoziemską przy użyciu rakiety ILR-33 Bursztyn, to ok. $10 \mathrm{~kg}$, czyli satelita klasy nano. Jest to masa nieco zaniżona w stosunku do pierwotnych założen projektowych dla systemu, jednakże fakt istnienia gotowej konstrukcji rakietowej ma kluczowe znaczenie dla ewentualnych dalszych decyzji odnośnie aplikowania konkretnego rozwiązania misyjnego. Stąd do wyznaczania parametrów osiągowych w charakterystycznych punktach profilu lotu wykorzystano dane uwzględniające właśnie tę rakietę.

Obliczenia osiągowe przeprowadzono z zastosowaniem specjalistycznego oprogramowania Aircraft Performance Program (APP) - [34], [35]. Program umożliwia dokładne zaprojektowanie profilu misji. Użytkownik projektuje go, wybierając różne segmenty lotu, np. start, wznoszenie, lot ustalony, krążenie, zrzut ładunku, zniżanie, a także definiuje niezbędne warunki i parametry. Pozwala to na symulację misji samolotu o dowolnym przeznaczeniu. APP na podstawie wprowadzonych danych w przeciągu kilku sekund określa zasięg, zużycie paliwa oraz inne parametry misji, a także umożliwia jej szybką optymalizację pod kątem maksymalnego zasięgu, długotrwałości lotu czy promienia działania. Użytkownik ma do dyspozycji wszechstronne narzędzie umożliwiające generowanie wykresów z pożądanymi charakterystykami osiągowymi, tzn. rozkłady parametrów w funkcji czasu lotu lub przebytej drogi.

Przed wykonaniem obliczeń profilu misji niezbędną czynnością jest utworzenie modelu osiągowego poprzez wprowadzenie do programu danych dotyczących masy, aerodynamiki oraz zespołu napędowego. Pozyskane dane dotyczące samolotu MiG-29 wymagały uporządkowania i sprowadzenia do formy tabelarycznej, akceptowalnej dla programu APP. W modelu konieczne jest zdeklarowanie następujących zależności:

- współczynnika siły nośnej $C_{L}$ od kąta natarcia dla różnych liczb Macha Ma,

- współczynnika siły nośnej od współczynnika oporu indukowanego $C_{D I}$ dla różnych Ma,

- współczynnika oporu przy zerowej sile nośnej $C_{D 0}$ od Ma [35].

W zakresie poddźwiękowych wartości Ma, tzn. od 0,3 do 0,7, wykorzystano charakterystyki uzyskane z własnych symulacji przeprowadzonych w oprogramowaniu FlightStream - udostępnione w [38]. Aby zasymulować pełny profil misji, należało jednak dokonać ekstrapolacji potrzebnych współczynników, uwzględniając zakresy prędkości około- i naddźwiękowych.

Współczynnik siły nośnej $C_{z a}$ został ekstrapolowany przy wykorzystaniu danych przedstawionych na wykresie zmian tego współczynnika w funkcji kąta natarcia (rys. 8), który zawarty jest w Instrukcji Techniki Pilotowania samolotu MiG-29 [33]. Z wykresu odczytano wartość maksymalną $C_{z a}$ dla $\mathrm{Ma}=1,2$, a następnie wartości współczynników dla liczb Ma od 0,7 do 1,2 aproksymowano, uwzględniając tempo przyrostu wartości $C_{z a}$ z przedziału liczb Macha od 0,3 do 0,7. Przy liczbach Ma powyżej 1,2 nachylenie przebiegu $C_{z a}(\alpha)$ zaczyna maleć. W przedziale $\mathrm{Ma}=1,2 \div 1,7$ założono liniowy spadek wartości $C_{z a}$. W przedziale liczb Ma od 0,8 do 1,2, czyli w zakresie okołodźwiękowym następuje gwałtowny przyrost wartości współczynnika opo$\mathrm{ru}$, ze względu na coraz większy udział oporu falowego [36]. We wspomnianym zakresie przebieg $C_{x 0}\left(C_{D i}\right)$ ma w przybliżeniu charakter liniowy. 


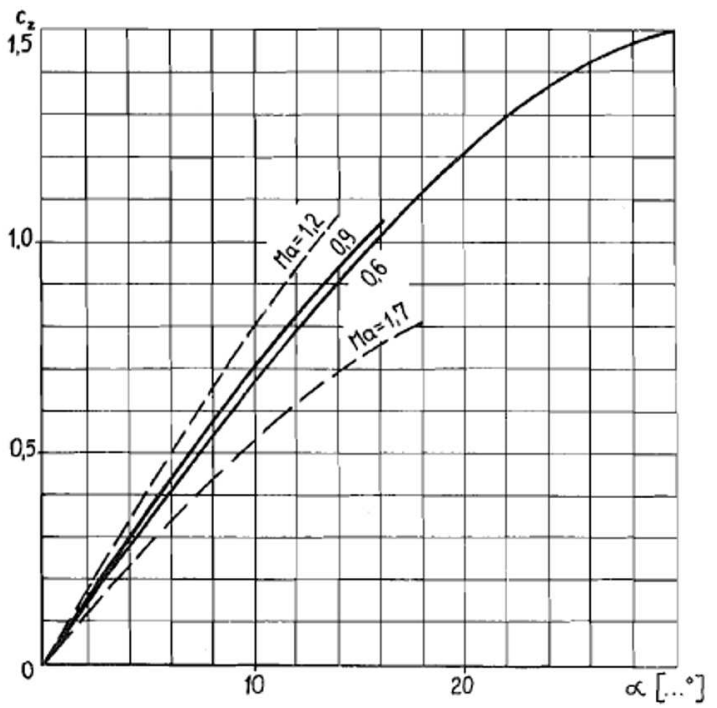

Rys. 8. Wykresy zmian współczynnika siły nośnej $C_{z}$ samolotu MiG-29 w funkcji kąta natarcia dla wybranych wartości Ma - przydatne do ekstrapolacji dla zakresu około- i naddźwiękowego [33]

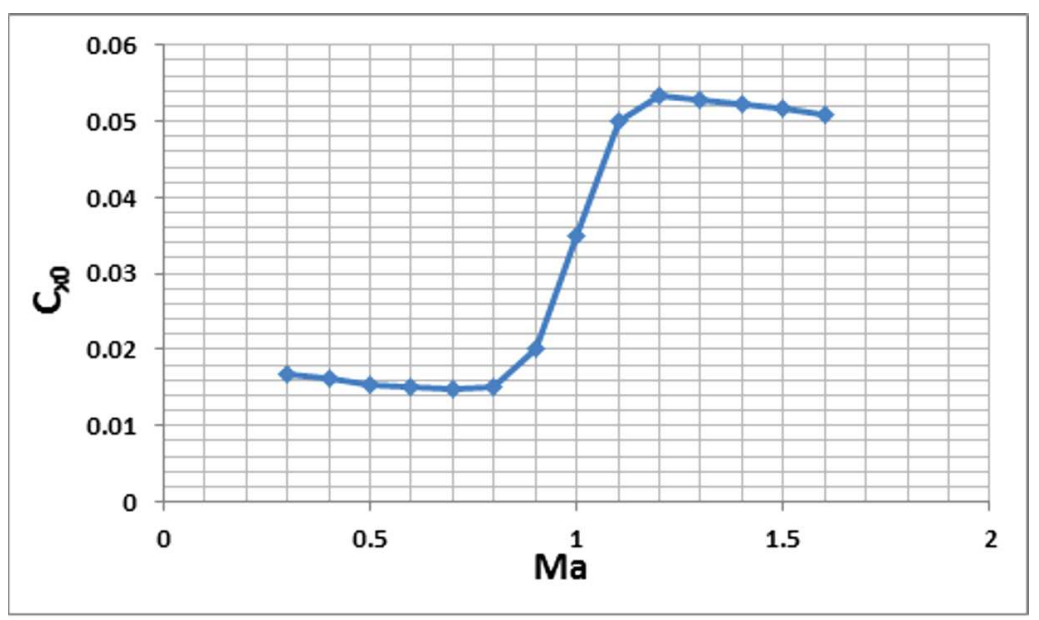

Rys. 9. Zmiana wartości współczynnika siły oporu przy zerowej sile nośnej samolotu MiG-29 w funkcji Ma; zauważalny przyrost skokowy ze względu na zjawisko oporu falowego [31]

Współczynnik siły oporu przy zerowej sile nośnej swoje maksimum osiąga dla liczby Macha ok. 1,2. Dla liczb Macha większych od 1,2 (zakres naddźwiękowy) wartości tego oporu nieznacznie maleją (rys. 9). Ekstrapolacja $C_{x 0}$ samolotu MiG-29 została przeprowadzona na podstawie wykresu przebiegów zależności $C_{x 0}(\mathrm{Ma})$ dla różnych samolotów bojowych przedstawionego w Aircraft Design: A Conceptual Approach D. Raymera [36]. Wzorowano się na krzywych dla samolotów F-15 oraz F-16, gdyż właśnie te myśliwce uznano za referencyjne. Do wartości oporu przy zerowej sile nośnej samolotu MiG-29 w konfiguracji z podwieszoną rakietą ILR-33 Bursztyn dodano wartość $C_{x 0}=0,0022$. Jest to wartość współczynnika oporu czołowego podwieszanego zbiornika paliwa PTB-1500 (tabela 3) samolotu MiG-29 i została zaczerpnięta z poz. Samoloty MiG-29 i MiG-29UB z silnikami RD-33. Obliczanie zasiegu i długotrwałości lotu [22].

W obliczeniach uwzględniono także opór indukowany. Jego współczynnik $C_{x i}$ (ang. $C_{D i}$ ) jest wprost proporcjonalny do kwadratu wytwarzanej przez skrzydło siły nośnej. Współczynnikiem proporcjonalności jest współczynnik $K$ [36]

$$
K=\frac{1}{\pi A e}
$$

gdzie: $A$ - wydłużenie płata nośnego, $e$ - współczynnik Oswalda, przyjęto $e=0,75$. 
Zatem wyrażenie na wartość współczynnika oporu indukowanego przybiera wg poz. [36], [37] znaną postać

$$
C_{x i}=K C_{z a}^{2}
$$

Współczynnik $K$ wyrażony zależnością (3.1) znajduje zastosowanie przy obliczaniu wartości oporu indukowanego w zakresie do Ma $=1 \mathrm{i}$ tak też poczyniono, ekstrapolując wartości oporu indukowanego. Dla liczb Macha powyżej 1 wartości $C_{x i}$ obliczono, stosując inny wzór [36]

$$
K=\frac{A\left(\mathrm{Ma}^{2}-1\right) \cos \Lambda_{L E}}{4 A \sqrt{\mathrm{Ma}^{2}-1}-2}
$$

gdzie $\Lambda_{L E}$ to kąt skosu skrzydła. Wartości współczynnika siły oporu indukowanego $C_{x i}$ obliczono dla liczb Macha w przedziale od 0,8 do 1,5 co 0,1, dla każdej wartości siły nośnej odpowiadającej kątom natarcia od $-4^{\circ}$ do $18^{\circ}$ co $1^{\circ}$.

Środowisko symulacyjne APP wymaga dość szczegółowych danych dotyczących jednostki napędowej: są to wartości maksymalne i minimalne ciągu dla różnych wysokości i liczb Macha na zakresie z dopalaniem i bez dopalania oraz wartości masowego natężenia przepływu paliwa w funkcji ciągu dla różnych liczb Macha oraz różnych wysokości, również na zakresie z dopalaniem i bez dopalania. Maksymalne wartości ciągu w zależności od liczby Ma i dla różnych pułapów na obu zakresach pracy silnika RD-33 odczytano z jego charakterystyki prędkościowowysokościowej dostępnej w poz. [22] (rys. 10).

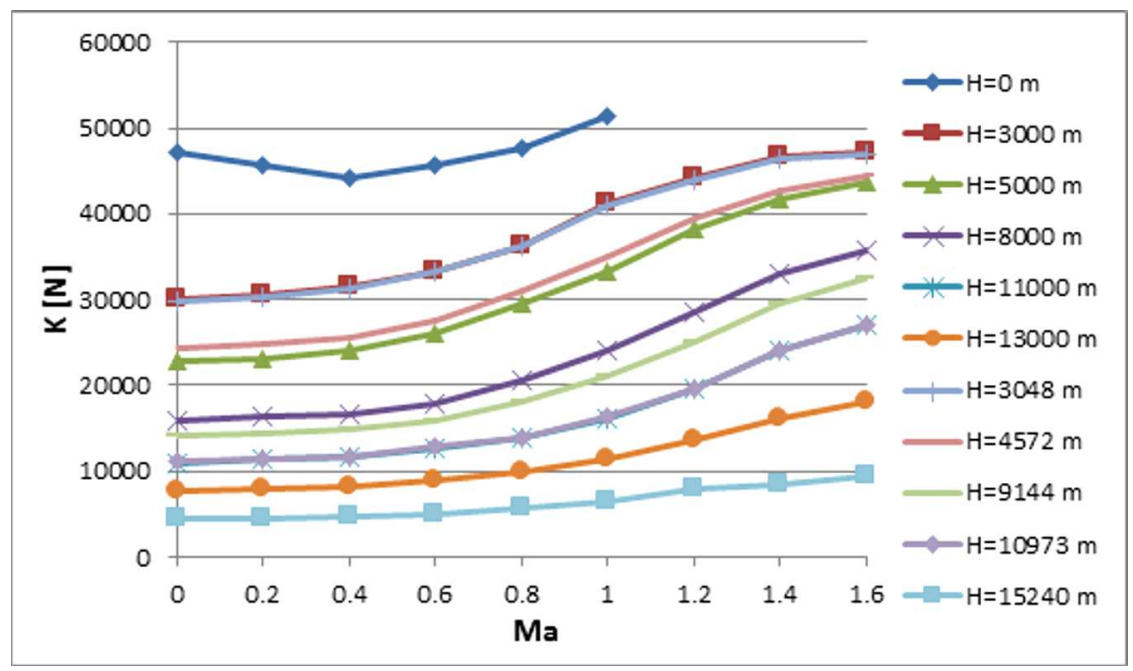

Rys. 10. Charakterystyki prędkościowo-wysokościowe silnika RD-33 na zakresie pracy - ciąg maksymalny (bez dopalania)

Dodatkowo skorzystano z wykresów jednostkowego zużycia paliwa w funkcji ciągu dla różnych liczb Macha, by pośrednio określić zależność zmiany masowego natężenia przepływu paliwa w funkcji ciągu, co pozwoliło na poznanie zapotrzebowania silnika na paliwo podczas lotu w zakresie prędkości i wysokości niezbędnych do wykonania założonego profilu misji. Wykresy tego typu jak na rys. 11 zawarte są jako załączniki w Aircraft Design: A Conceptual Approach D. Raymera [36]. Sa to modelowe przebiegi dla dwuprzepływowego turbinowego silnika odrzutowego z dopalaczem, o małym stopniu dwuprzepływowości. Silnik ten jednak jest nieco większy od silnika RD-33 (maksymalny ciąg przy włączonym dopalaczu to ok. $133 \mathrm{kN}$, podczas gdy w przypadku silnika RD-33 jest to niespełna $80 \mathrm{kN}$ ). Założono więc, że uzyskiwane wartości masowego natężenia przepływu paliwa są nieco zawyżone i przemnożono je przez odpowiednio dobrany współczynnik, uwzględniający różnicę w masie i wymiarach pomiędzy silnikiem RD-33 a teoretycznym silnikiem, którego dotyczyły dane literaturowe. Ostatecznie otrzymano szereg wykresów obrazujących zmianę zapotrzebowania silnika na paliwo wraz ze wzrostem ciągu (rys. 12). 


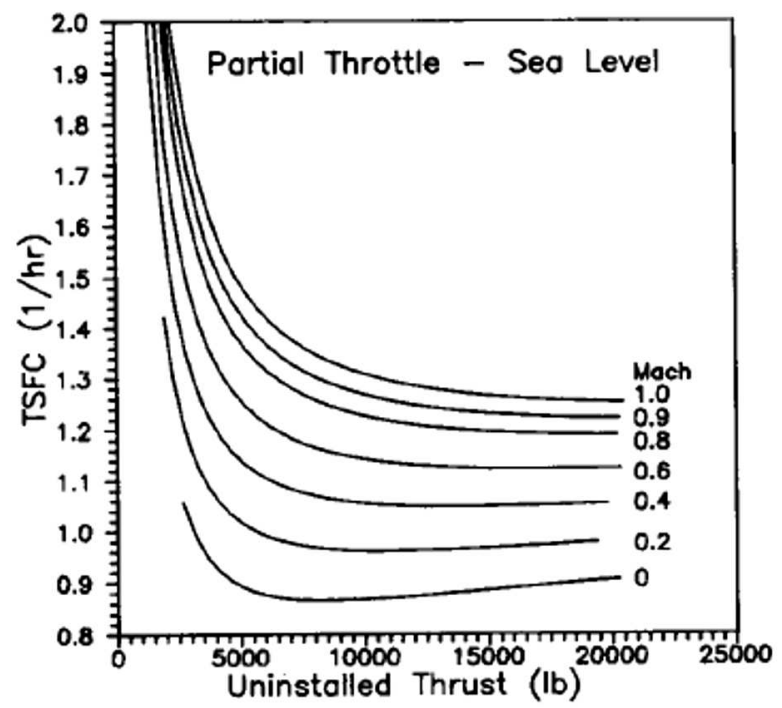

Rys. 11. Wykres jednostkowego zużycia paliwa w funkcji ciągu dla różnych liczb Ma na zakresie pracy bez dopalania; tego typu wykresy - każdy dla innego pułapu - posłużyły do wyznaczenia zależności masowego natężenia przepływu paliwa w funkcji ciągu [36]

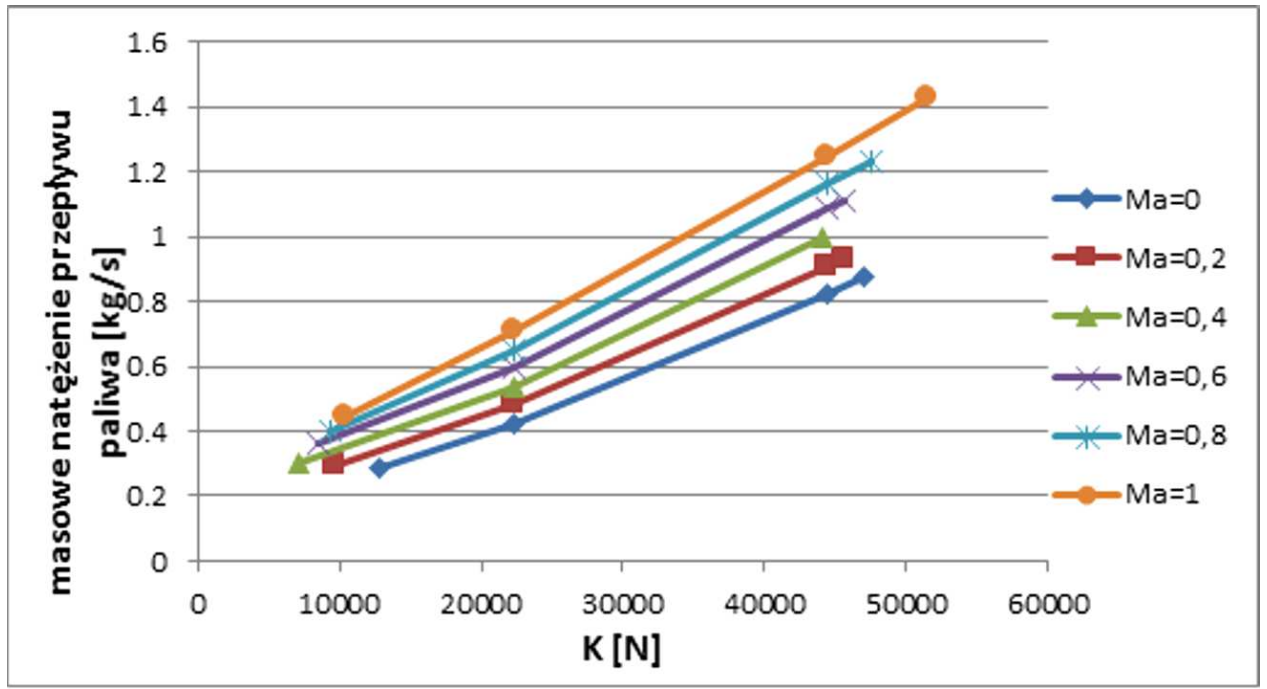

Rys. 12. Zmiana masowego natężenia przepływu paliwa $\dot{m}_{p a l}$ w funkcji ciągu silnika RD-33 dla różnych liczb Ma na wysokości $H=0 \mathrm{~m}$ przy pracy na zakresie bez dopalania

Charakterystyka prędkościowo-wysokościowa zawiera dane przedstawione w jednostkach metrycznych, natomiast wykresy zużycia paliwa w funkcji ciągu, tak jak widać na rys. 11 przedstawiają wartości w jednostkach imperialnych. Środowisko APP wymaga, aby dane silnikowe dotyczące maksymalnych wartości ciągu, jak i zużycia paliwa, były ze sobą spójne, tj. pułapy, dla których są definiowane oba rodzaje danych, były identyczne [35]. Wykresy zużycia paliwa zostały opisane w stopach, tzn. dla wysokości: $0 \mathrm{ft}, 15000 \mathrm{ft}, 30000 \mathrm{ft}, 36000 \mathrm{ft}, 50000 \mathrm{ft}$, co po konwersji daje odpowiednio: $0 \mathrm{~m}, 4572 \mathrm{~m}, 9144 \mathrm{~m}, 10973 \mathrm{~m}, 15240 \mathrm{~m}$. Użyta charakterystyka prędkościowo-wysokościowa zawiera dane dla pułapów: $0 \mathrm{~m}, 3000 \mathrm{~m}, 5000 \mathrm{~m}, 8000 \mathrm{~m}, 11000 \mathrm{~m}$, $13000 \mathrm{~m}, 20000 \mathrm{~m}$. Maksymalne wartości ciągu zostały więc zaproksymowane na pułapach pośrednich, czyli takich, jakie otrzymano, przeliczając z wartości w jednostkach imperialnych, co tłumaczy dobór wysokości przedstawionych na rys. 10. 


\section{Obliczenia parametrów osiągowych i uzyskane charakterystyki}

Przed wykonaniem obliczeń profilu misji niezbędną czynnością jest utworzenie modelu samolotu poprzez wprowadzenie odpowiednich danych dotyczących masy, aerodynamiki oraz jednostki napędowej statku powietrznego [35]. Pozyskane dane na temat samolotu MiG-29 wymagały uporządkowania i sprowadzenia do formy tabelarycznej (rys. 13). W zakładce Mass $\&$ limits wprowadzane sa dane masowe takie jak: masa własna samolotu, masa paliwa, masa załogi. Deklaruje się tam liczbę silników, ekstremalne przeciążenia i kąty natarcia, maksymalną masę startową oraz maksymalne liczby Macha dla uwzględnianych pułapów. W zakładce Aerodynamics deklarowane są parametry geometryczne płatowca. W stabelaryzowanej formie zestawiane są wartości współczynników aerodynamicznych w funkcji kąta natarcia dla uwzględnianego zakresu obliczeniowego liczb Ma. Dla zakresu małych prędkości wykorzystano dane wynikowe z własnych obliczeń przeprowadzonych w programie FlightStream, które udostępnione są w opracowaniu [38], natomiast dla przedziału wyższych liczb Ma, od 0,8 do 1,5, zastosowano dane ekstrapolacyjne.

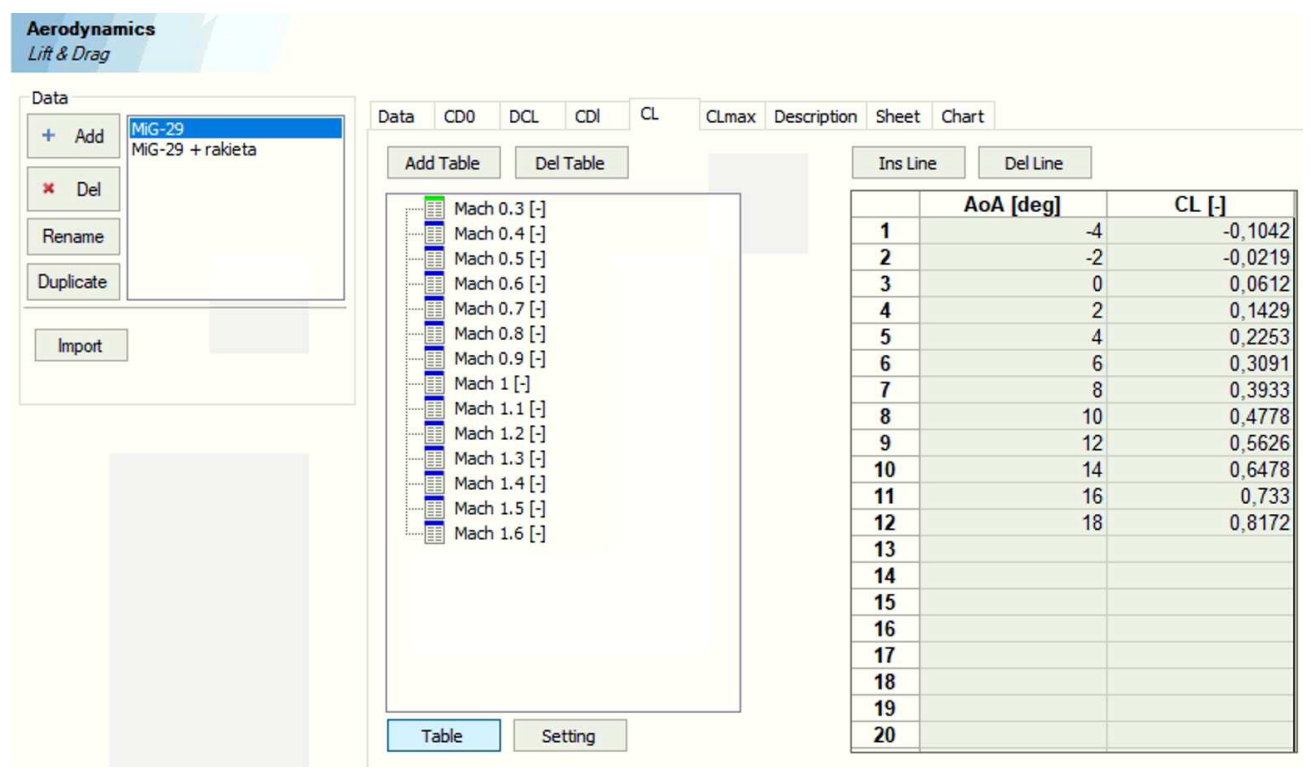

Rys. 13. Przykładowy arkusz danych wsadowych do programu APP - parametry aerodynamiczne

W zakładce Propulsion wprowadzono dane silnika RD-33 takie jak: wartości maksymalnego i minimalnego ciągu silnika w funkcji liczby Macha dla różnych wysokości, a także wartości masowego natężenia przepływu paliwa w funkcji ciągu silnika dla różnych liczb Macha i pułapów. Informacje te - jak zostało to wcześniej wyjaśnione - zostały zaczerpnięte z charakterystyki prędkościowo-wysokościowej silnika RD-33 [22] oraz z wykresów jednostkowego zużycia paliwa w funkcji ciągu dla różnych liczb Ma i wysokości typowego dwuprzepływowego turbinowego silnika odrzutowego o małym podziale masowego natężenia przepływu powietrza przedstawionych jako załączniki w Aircraft Design: A Conceptual Approach D. Raymera [29]. Uwzględniono zakres pracy silnika bez dopalania, jak i z dopalaniem.

W analizie uwzględniono następujące konfiguracje obiektu misyjnego: pierwsza - z podwieszoną rakietą, skrzydło bez wychylonych elementów mechanizacji, silnik pracujący na zakresie dopalania, druga - jak poprzednio, silnik pracujaccy na zakresie ciągu maksymalnego, trzecia bez podwieszenia, skrzydło bez wychylonych elementów mechanizacji, silnik pracujący na zakresie ciągu maksymalnego.

Profil misji określono z zachowaniem podobieństwa do profilu wstępnie zakładanego. Ostatecznie uwzględniono następujące odcinki (rys. 14): 0-1 - uruchomienie silników i kołowanie, 
1-2 - start, 2-3 - wznoszenie na wysokość $H=9000 \mathrm{~m}, 3-4$ - lot poziomy ustalony z prędkością Ma $=0,77,4-5$ - rozpędzanie $\mathrm{w}$ locie poziomym do prędkości naddźwiękowej Ma $=1,2$, 5-6 - manewr zoom climb z dynamicznym wznoszeniem do wysokości $H=12500 \mathrm{~m}$ zakończonym separacją rakiety, 6-7 - zniżanie z jednoczesnym wytracaniem prędkości, 7-8 - lądowanie.

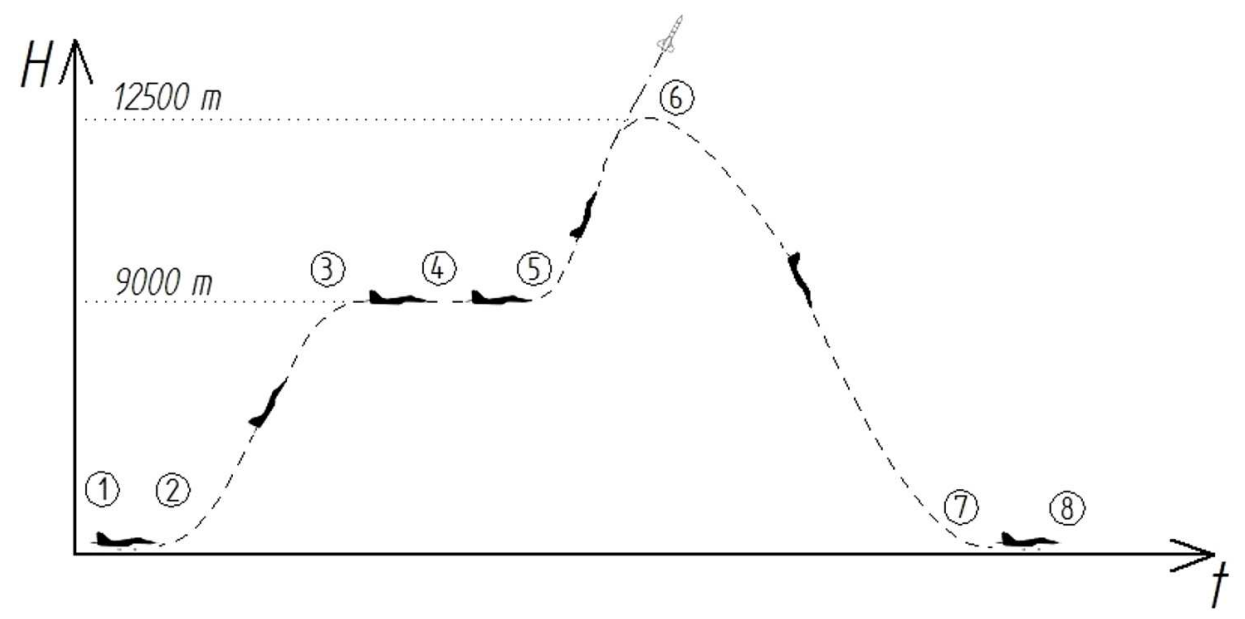

Rys. 14. Profil misji do obliczeń w programie APP: 1-2 - start, 2-3 - wznoszenie z rozpędzaniem,

3-4 - lot ustalony, 4-5 - rozpędzanie, 5-6 - manewr zoom climb, 6-7 - zniżanie, 7-8 - lądowanie

Definicję misji w środowisku APP rozpoczęto od określenia wielkości początkowych, jak: wysokość lotu, prędkość, procentowa ilość paliwa w zbiornikach (100\% wg wartości podanej w tabeli 4). Program APP umożliwia wybór typowych segmentów misyjnych, takich jak start, wznoszenie, krążenie, a także nietypowych, jak tankowanie w powietrzu. Użytkownik musi zdefiniować warunek zakończenia danego segmentu lotu. Warunek ten jest pewnym parametrem, którego spełnienie powoduje wstrzymanie iteracyjnych obliczeń i przejście do kalkulacji w kolejnym segmencie. Przykładowo, warunkiem końcowym w etapie rozpędzania najczęściej będzie prędkość, którą samolot ma osiągnąć.

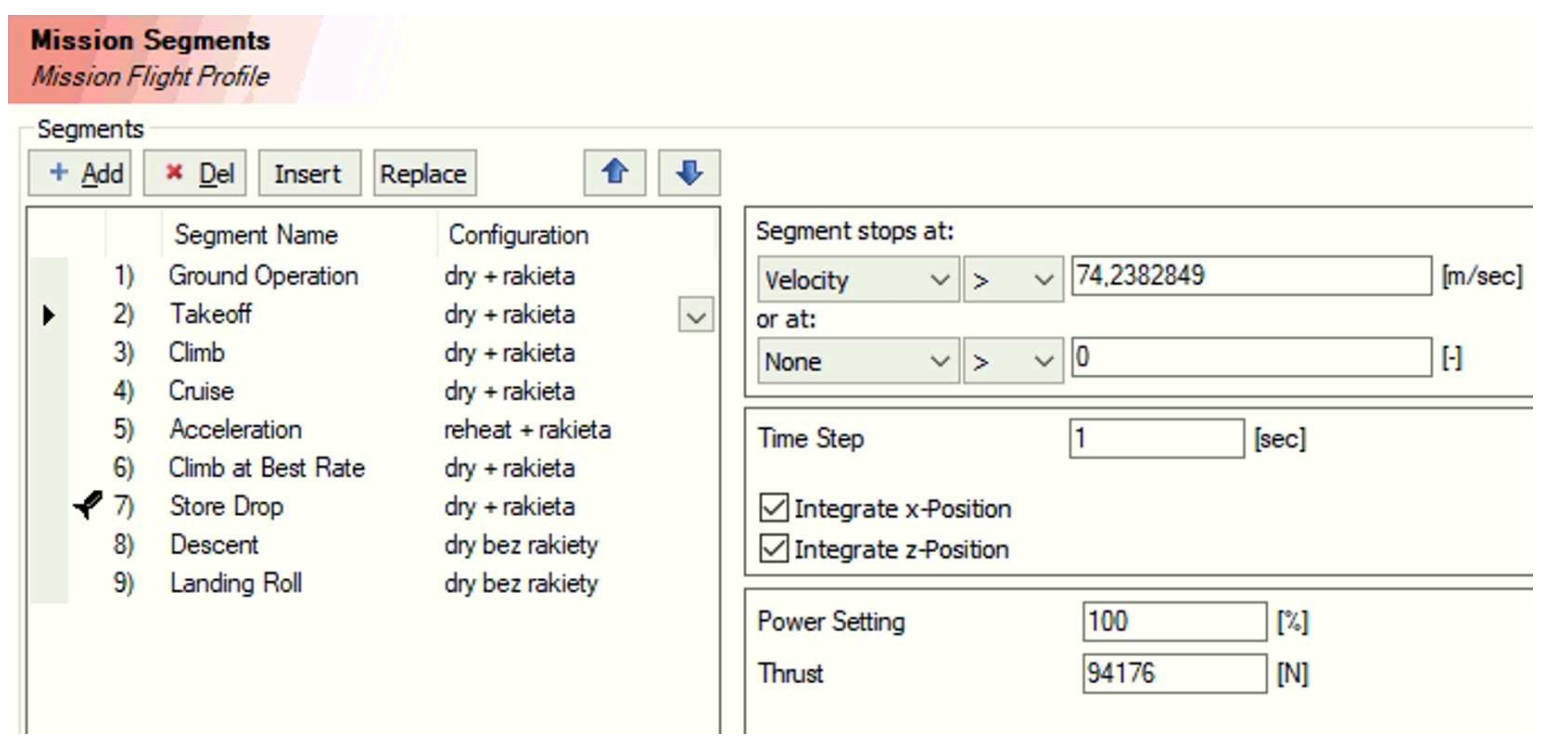

Rys. 15. Określanie profilu misji w APP - widoczna lista wybieralnych segmentów przelotu

Pierwszym wybranym segmentem profilu misji jest segment Ground Operation, którym zasymulowano operacje naziemne, tj. uruchomienie i podgrzanie silników oraz kołowanie. Czas trwania określono na 5 minut. Start samolotu odwzorowano segmentem Takeoff, którego ko- 
niec określono prędkością 74,24 m/s. Wznoszenie zasymulowano segmentem Climb, który trwa do osiągnięcia przez samolot wysokości $9000 \mathrm{~m}$. Przyspieszenie w toku wznoszenia ustalono na $0,372 \mathrm{~m} / \mathrm{s}^{2}$; utrzymanie tej wartości gwarantuje osiągnięcie liczby Ma $=0,77 \mathrm{w}$ końcowym punkcie segmentu. Wznoszenie następuje na maksymalnym zakresie pracy silników (bez dopalania). Następnie zakłada się fazę lotu poziomego ustalonego na odcinku $25 \mathrm{~km}$. Etapem Acceleration zasymulowano przyspieszanie do prędkości naddźwiękowej odpowiadającej Ma $=1,2$. Kłopotliwe okazało się odwzorowanie manewru zoom climb ze względu na to, że program APP nie oferuje do wyboru dokładnie takiego segmentu. Skorzystano więc z zastępczego etapu Climb at Best Rate, czyli wznoszenia z możliwie najwyższą prędkością pionową, dodatkowo ustalając pracę silników na biegu jałowym. Taka realizacja wznoszenia odpowiada zamianie energii kinetycznej samolotu na energię potencjalną wysokości, tak jak ma to miejsce w rzeczywistym manewrze zoom climb. Następnie przewidziano odrzucenie rakiety, co odpowiada programowemu odcinkowi Store Drop. Zniżanie na biegu jałowym odwzorowano etapem Descent, dobierając przyspieszenie na poziomie $-0,11 \mathrm{~m} / \mathrm{s}^{2}$ tak, aby tuż przed przyziemieniem samolot miał prędkość bliską prędkości minimalnej, tzn. $62,5 \mathrm{~m} / \mathrm{s}$, co odpowiada liczbie $\mathrm{Ma}=0,184$. Ostatnim segmentem jest Landing roll, czyli lądowanie z dokołowaniem do prędkości zerowej.

Tabela 6. Etapy misji wraz z odpowiadającymi im segmentami wybranymi w środowisku APP

\begin{tabular}{|c|c|}
\hline Etap misji & Nazwa wybranego segmentu i etapu misji \\
\hline \hline $0-1$ & Ground operation - Uruchomienie silników i kołowanie \\
\hline $1-2$ & Takeoff - Start \\
\hline $2-3$ & Climb - Wznoszenie \\
\hline $3-4$ & Cruise - Lot poziomy ustalony \\
\hline $4-5$ & Acceleration - Rozpędzanie \\
\hline \multirow{2}{*}{$5-6$} & Climb at Best Rate - Manewr zoom climb \\
\cline { 2 - 2 } & Store drop - Odrzucenie rakiety \\
\hline $6-7$ & Descent - Zniżanie \\
\hline $7-8$ & Landing roll - lądowanie \\
\hline
\end{tabular}

Programowy tor misji miał być w założeniu możliwie najbardziej zgodny z profilem wstępnie zaproponowanym na rys. 6. Maksymalna prędkość na koniec etapu rozpędzania do prędkości naddźwiękowej na pułapie $H=9000 \mathrm{~m}$ w profilu wstępnym odpowiada liczbie Ma $=1,5$, natomiast $\mathrm{w}$ analizie programowej liczba ta jest niższa $\mathrm{Ma}=1,2 \mathrm{~W}$ programie APP przeprowadzono symulację misji, przyjmując początkową masę paliwa równą $3330 \mathrm{~kg}$ (100\% paliwa w zbiornikach integralnych).

Wyniki analizy programowej przedstawiono w zbiorczej tabeli 7. Całkowity czas trwania misji wynosi 37 min $12 \mathrm{~s}$. Najdłużej trwającym segmentem okazało się zniżanie trwające niespełna 21 minut. Całkowity dystans poziomy przebyty przez samolot w czasie wykonywania misji został oszacowany na poziomie $282 \mathrm{~km}$. Etap, w którym pokonano największą odległość, to zniżanie, gdzie samolot przebył około $165 \mathrm{~km}$. Czas trwania misji zasymulowanej w środowisku APP jest bardzo zbliżony do czasu wstępnie oszacowanego przy użyciu wykresów z instrukcji Samoloty MiG-29 i MiG-29UB z silnikami RD-33. Obliczanie zasięgu i dtugotrwałości lotu [22], gdzie wyniósł 35 min $34 \mathrm{~s}$. Wyliczona wówczas odległość była jednak nieco mniejsza i wyniosła $201 \mathrm{~km}$ (tabela 6).

Wyznaczono wykresy przedstawiające zależności wysokości, na jakiej znajduje się w danej chwili obiekt misyjny, od przebytego dystansu oraz od czasu (rys. 16 i 17). Uwagę zwraca krzywa dla manewru zoom climb, gdzie następuje raptowne wznoszenie na pułap $H=12500 \mathrm{~m}$. Na rys. 16 etapy operacji naziemnych, startu oraz odrzucenia rakiety nie są zauważalne, gdyż w ich 
Tabela 7. Lista poszczególnych etapów lotu obiektu misyjnego wraz z wybranymi parametrami etapowymi przy wariancie z początkową masą paliwa równą $3330 \mathrm{~kg}$ (100\% paliwa integralnego)

\begin{tabular}{|c|c|c|c|c|c|c|c|c|c|c|}
\hline 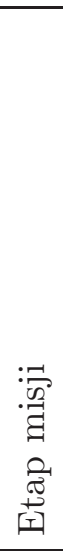 & 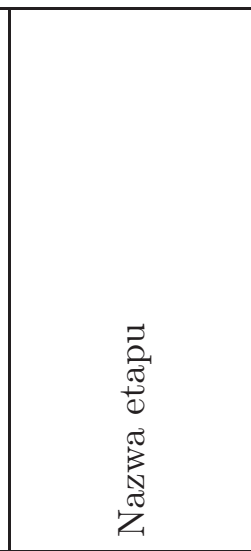 & 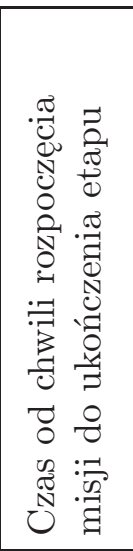 & 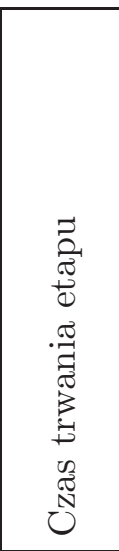 & 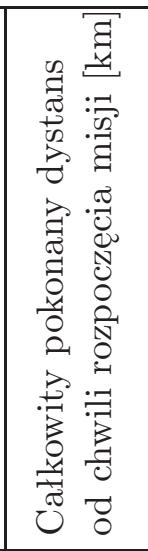 & 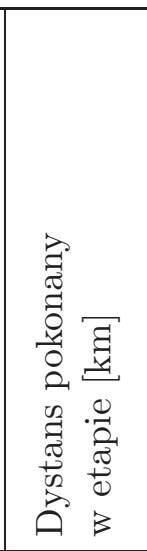 & 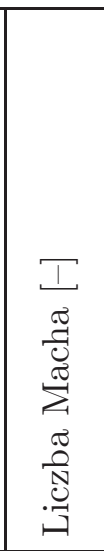 & 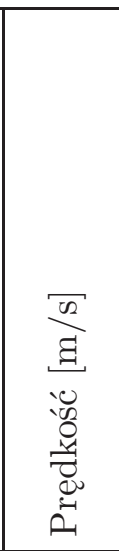 & 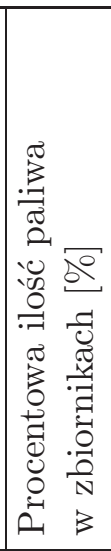 & 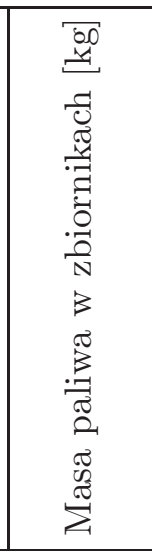 & 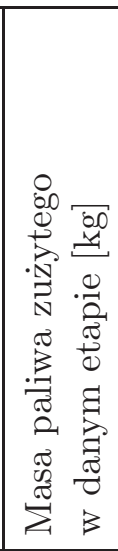 \\
\hline $0-1$ & $\begin{array}{l}\text { Rozruch } \\
\text { silników } \\
\text { i kołowanie }\end{array}$ & $5 \min$ & $5 \min$ & - & - & - & - & 94,47 & 3143,96 & 184,04 \\
\hline $1-2$ & Start & $\begin{array}{c}5 \min \\
12 \mathrm{~s} \\
\end{array}$ & $12 \mathrm{~s}$ & 0,468 & 0,468 & 0,218 & 74,24 & 93,75 & 3120 & 23,96 \\
\hline $2-3$ & Wznoszenie & $\begin{array}{c}12 \mathrm{~min} \\
26 \mathrm{~s}\end{array}$ & $\begin{array}{c}7 \min \\
14 \mathrm{~s}\end{array}$ & 66,041 & 65,573 & 0,77 & 233,8 & 78,47 & 2611,48 & 508,52 \\
\hline $3-4$ & \begin{tabular}{|l} 
Lot poziomy \\
ustalony
\end{tabular} & $\begin{array}{c}14 \min \\
13 \mathrm{~s}\end{array}$ & $\begin{array}{c}1 \mathrm{~min} \\
47 \mathrm{~s}\end{array}$ & 91,041 & 25 & 0,77 & 233,79 & 76,37 & 2541,59 & 69,89 \\
\hline $4-5$ & Rozpędzanie & $\begin{array}{c}15 \text { min } \\
29 \mathrm{~s}\end{array}$ & $\begin{array}{c}1 \mathrm{~min} \\
16 \mathrm{~s}\end{array}$ & 115,413 & 24,372 & 1,2 & 364,55 & 68,98 & 2295,65 & 245,94 \\
\hline $5-6$ & $\begin{array}{l}\text { Manewr zoom } \\
\text { climb i odrzu- } \\
\text { cenie rakiety }\end{array}$ & $\begin{array}{c}15 \min \\
44 \mathrm{~s}\end{array}$ & $15 \mathrm{~s}$ & 116,648 & 1,235 & 0,677 & 199,73 & 68,86 & 2291,66 & 3,99 \\
\hline 6-7 & Zniżanie & $\begin{array}{c}36 \mathrm{~min} \\
42 \mathrm{~s}\end{array}$ & $\begin{array}{c}20 \mathrm{~min} \\
58 \mathrm{~s}\end{array}$ & 280,895 & 164,247 & 0,184 & 62,5 & 52,47 & 1746,2 & 545,46 \\
\hline $7-8$ & Lądowanie & $\begin{array}{c}37 \text { min } \\
12 \mathrm{~s}\end{array}$ & $30 \mathrm{~s}$ & 281,768 & 0,873 & 0 & 0 & 51,92 & 1727,9 & 18,3 \\
\hline
\end{tabular}

trakcie pokonywana jest znikoma odległość w skali całego wykresu. Wyznaczono także przebieg zmiany masy samolotu w funkcji czasu (rys. 18). Obrazuje on wpływ na masę obiektu misyjnego, zarówno zużycia paliwa w poszczególnych etapach lotu, jak i odrzucenia podwieszonej rakiety pod koniec manewru zoom climb, co jest uwidocznione jako skokowy spadek masy.

Dodatkowo określono zależność kąta wznoszenia od wysokości dla etapu 2-3, czyli wznoszenia na pułap $H=9000 \mathrm{~m}$. Na samym początku etapu kąt ten wynosi około $26,4^{\circ}$ i stopniowo spada do wartości minimalnej $2,2^{\circ}$ w skrajnym górnym punkcie wznoszenia. Przeprowadzono także analizę wpływu początkowej masy paliwa na całkowite zużycie paliwa w trakcie wykonywania misji. Zbadano i porównano cztery warianty, w których znajdowało się w zbiornikach odpowiednio 100\%, 90\%, 80\% i 70\% maksymalnej masy paliwa. Analizy wykazały, że obiekt misyjny nie przejawia praktycznie żadnej wrażliwości na zmianę początkowej ilości paliwa w zbiornikach. W każdym z wybranych wariantów została zużyta bardzo podobna ilość paliwa - ok. $48 \%$ maksymalnej masy paliwa, czyli w przybliżeniu $1600 \mathrm{~kg}$. Jest to poniekąd sprzeczne z intuicją, gdyż mniejsza masa oznacza większy stosunek ciągu do masy statku powietrznego, co teoretycznie powinno przełożyć się na niższe zużycie paliwa. 


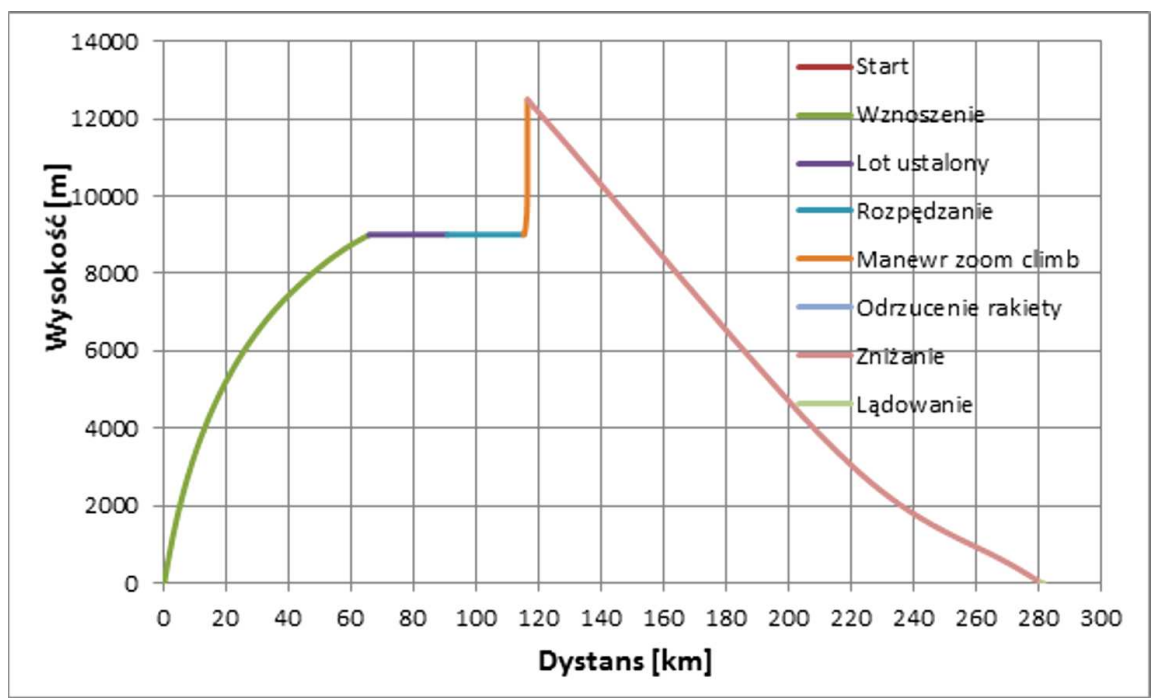

Rys. 16. Zależność chwilowej wysokości samolotu MiG-29 wykonującego założoną misję od przebytego dystansu dla każdego segmentu misji

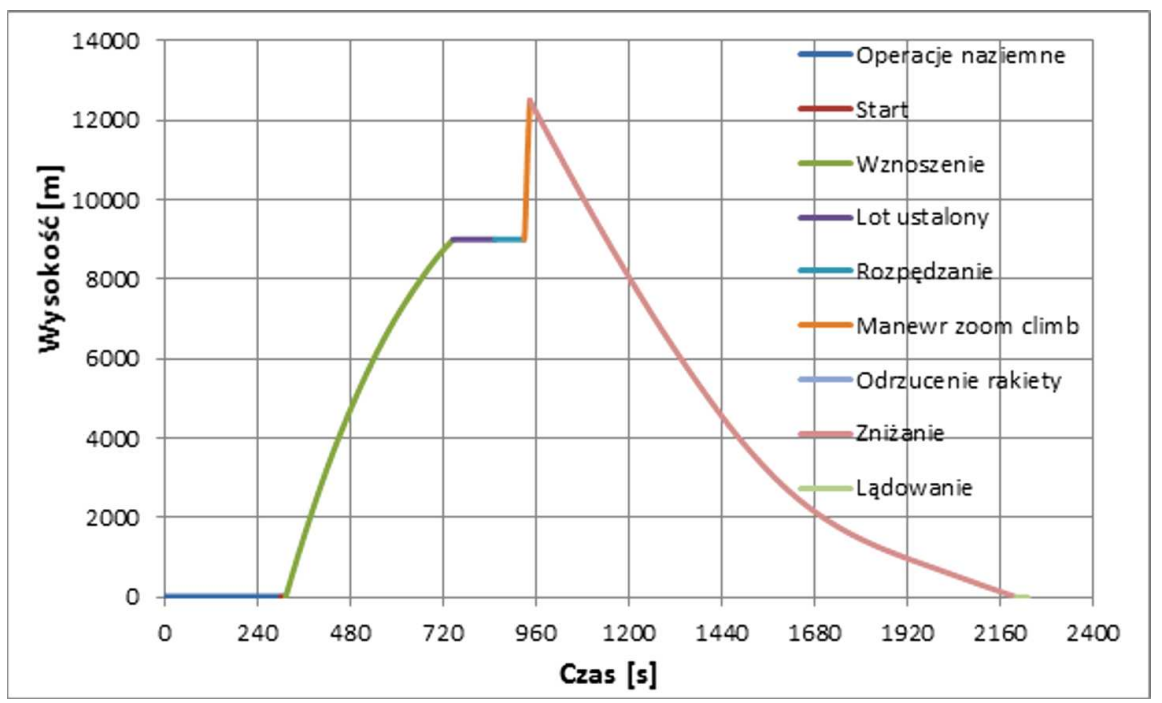

Rys. 17. Zależność chwilowej wysokości samolotu MiG-29 z rakietą od czasu misji

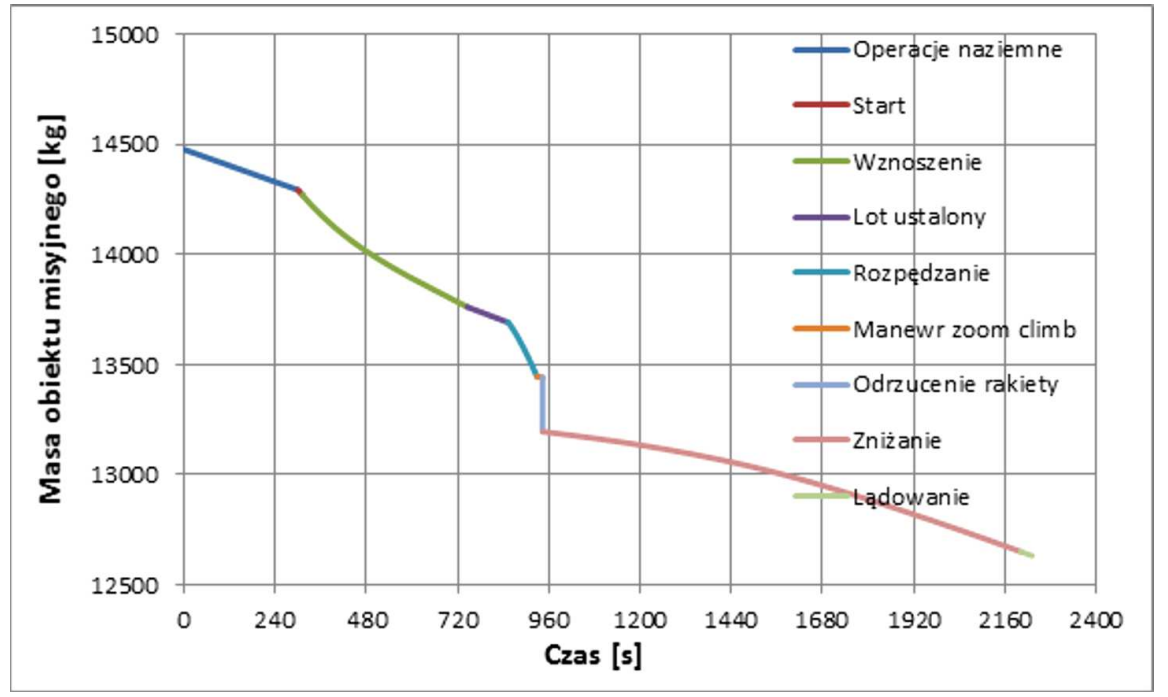

Rys. 18. Zależność masy samolotu MiG-29 z podwieszoną rakietą od czasu misji 


\section{Uwagi końcowe}

W analizie konfiguracji masowej lotniczo-rakietowego systemu transportującego mały ładunek satelitarny zaproponowano wykorzystanie rakiety ILR-33 Bursztyn. Jest to konstrukcja opracowana i rozwijana przez rodzimy instytut badawczy, toteż jej ewentualna adaptacja do spełniania roli podwieszanego nośnika nanosatelitów byłaby łatwiejsza. Masa tej rakiety określona na podstawie modelu geometrycznego w systemie Siemens NX wynosi $247 \mathrm{~kg}$. Konstruktorzy ILR-33 Bursztyn szacują, że ich rakieta będzie w stanie wynieść nawet $10 \mathrm{~kg}$ ładunek na wysokość $100 \mathrm{~km}$. Korzystając z wyznaczonych w pracy zależności trendowych, masa ładunku rakiety zazwyczaj stanowi od 2 do 2,5\% jej masy całkowitej. Sugerując się masą przypisaną wirtualnemu modelowi rakiety, łatwo obliczyć, że rakieta ILR-33 Bursztyn mogłaby wynieść satelitę o masie maksymalnej około $6 \mathrm{~kg}$, co jest wartością nieco zaniżoną w stosunku do oczekiwań projektowych. Jednakże należy zauważyć, że aproksymacja masy w modelu wirtualnym jest z pewnością obarczona pewnym błędem. Co więcej, zastrzeżenie budzi docelowy pułap osiągany przez ILR33 Bursztyn. Wysokość $100 \mathrm{~km}$, na której znajduje się umowna granica między atmosferą Ziemi a przestrzenią kosmiczną, czyli tzw. linia Karmana, jest niewystarczająca, by satelita utrzymał się na stałej orbicie. Na pułapie tym orbitujący obiekt nadal doświadcza oporu aerodynamicznego, który skutecznie go spowalnia i może doprowadzić do zejścia w jeszcze niższe warstwy atmosfery, co skutkowałoby zniszczeniem satelity. Optymalny pułap, na który użyta rakieta powinna wynieść ładunek, mieści się w przedziale od 150 do $200 \mathrm{~km}$.

Udowodniono w sposób analityczny oraz poprzez wykorzystanie komputerowego programu symulacyjnego, że wykonanie założonego profilu misji przez samolot MiG-29 z podwieszoną rakietą ILR-33 Bursztyn jest możliwe. Profile misyjne określone na potrzeby obliczeń wstępnych, a potem programowych, nieznacznie się od siebie różnią, mimo to otrzymano w nich bardzo podobne wartości czasu wykonania misji oraz masy zużytego paliwa - szacowany czas to ok. 35-37 min, a zużyte paliwo stanowi ok. 50\% masy paliwa w zbiornikach. Rozpatrywano wariant całkowitego napełnienia zbiorników paliwem, a więc okazało się, że po wykonaniu zadania w samolocie nadal pozostaje aż połowa paliwa. Niemniej jednak przy wykorzystaniu parametrycznego modelu symulacyjnego nie stwierdzono, by mniejsza początkowa masa paliwa wpłynęła na jego zużycie w locie, co jest poniekąd sprzeczne z intuicją. Wyjaśnienie tej wątpliwości wymaga podjęcia dalszych nieco bardziej szczegółowych analiz.

Publikacja prezentuje analizy i wyniki opracowane w toku realizacji Grantu Badawczego MON nr 13989/2018/WAT pt. „Lotniczo-rakietowy system wynoszenia tadunków na niska orbite okołoziemska - studium realizowalności"; praca jest finansowana ze środków Ministerstwa Obrony Narodowej i realizowana w Wydziale Mechatroniki, Uzbrojenia i Lotnictwa Wojskowej Akademii Technicznej w latach 2018-2022.

\section{Bibliografia}

1. Van Kesteren M.W., Air Launch versus Ground Launch: a Multidisciplinary Design Optimization Study of Expendable Launch Vehicles on Cost and Performance, Master of Science Thesis, Delft University of Technology, Faculty of Aerospace Engineering, Delft, 2013

2. Torecki S., Napędy lotnicze. Silniki rakietowe, Wydawnictwa Komunikacji i Łączności, Warszawa, 1984

3. Cakaj S., Kamo B., Lala A., Rakipi A., The coverage analysis for low earth orbiting satellites at low elevation, International Journal of Advanced Computer Science and Applications, 5, 6, 2014, https://thesai.org/Downloads/Volume5No6/Paper_2-The_Coverage_Analysis_for_Low_Earth_ Orbiting_Satellites_at_Low_Elevation.pdf

4. Scotт J., NOTSNIK, Project Pilot and Project Caleb, aerospaceweb.org [online], 2006, http://www.aerospaceweb.org/question/spacecraft/q0271.shtml 
5. Pilot (NOTSNIK), Directory of U.S. Military Rockets and Missiles. Appendix 4: Undesignated Vehicles [online], 2003, http://www.designation-systems.net/dusrm/app4/notsnik.html

6. NOTS-EV-1 Pilot, Wikipedia, The Free Encyclopedia [online] 2019, https://en.wikipedia.org/wiki/NOTS-EV-1_Pilot

7. Glenshaw P., The First Space Ace. F-15 vs. Satellite, Air and Space Magazine, [online], 2018, https://www.airspacemag.com/military-aviation/first-space-ace-180968349/

8. ASM-135 ASAT, Wikipedia, The Free Encyclopedia [online], 2019, https://en.wikipedia.org/wiki/ASM-135_ASAT

9. Pegasus. Patented Air Launch System, Northrop Grumman [online], 2019, https://www.northropgrumman.com/Capabilities/Pegasus/Documents/Pegasus_Factsheet.pdf

10. Pegasus (Rocket), Wikipedia, The Free Encyclopedia [online], 2019, https://en.wikipedia.org/wiki/Pegasus_(rocket)

11. Pegasus User's Guide, Orbital ATK, [online], 2015, https://web.archive.org/web/20170623144151/ http://www.orbitalatk.com/flight-systems/spacelaunch-vehicles/pegasus/docs/Pegasus_UsersGuide.pdf

12. Chen T., Ferguson P., Deamer D., Hensley J., Responsive air launch using F-15 global strike eagle, 4th Responsive Space Conference, [online], 2006, http://citeseerx.ist.psu.edu/viewdoc/download?doi=10.1.1.560.4885\&rep=rep1\&type=pdf

13. Mikoyan MiG-29, Wikipedia, The Free Encyclopedia [online], 2019, https://en.wikipedia.org/wiki/Mikoyan_MiG-29

14. R-60 (missile), Wikipedia, The Free Encyclopedia [online], 2019, https://en.wikipedia.org/wiki/R-60_(missile)

15. Raytheon (Philco/General Electric) AAM-N-7/GAR-8/AIM-9 Sidewinder, Directory of U.S. Military Rockets and Missiles, [online], 2008, http://www.designation-systems.info/dusrm/m-9.html

16. R-27 „Wympiet”, samolotypolskie.pl [online], 2019, http://www.samolotypolskie.pl/samoloty/2474/126/R-27

17. AGM-88 HARM, FAS. Military Analysis Network [online], 2019, https://fas.org/man/dod-101/sys/smart/agm-88.htm

18. Zwiezda Ch-25, samolotypolskie.pl [online], 2019, http://www.samolotypolskie.pl/samoloty/2454/91/Zwiezda-Ch-252

19. AGM-65 Maverick, Wikipedia, The Free Encyclopedia [online], 2019, https://en.wikipedia.org/wiki/AGM-65_Maverick

20. Harpoon, Missile Threat [online], 2018, https://missilethreat.csis.org/missile/harpoon/

21. R-33 (missile), Wikipedia, The Free Encyclopedia [online], 2019, https://en.wikipedia.org/wiki/R33_(missile)

22. Samoloty MiG-29 i MiG-29UB z silnikami RD-33. Obliczanie zasiegu i długotrwałości lotu, Dowództwo Wojsk Lotniczych i Obrony Powietrznej, Poznań, 1992

23. Wiatrek R., Teoria silników lotniczych, Wojskowa Akademia Techniczna im. Jarosława Dąbrowskiego, Warszawa, 1983

24. Atmosfera wzorcowa, Wikipedia, The Free Encyclopedia [online], 2019, https://pl.wikipedia.org/wiki/Atmosfera_wzorcowa

25. KrzyżAnowski A., Mechanika lotu, Wojskowa Akademia Techniczna, Warszawa, 2009

26. Rzut ukośny. Opis ruchu, Fizykon, [online], 2019, http://www.fizykon.org/kinematyka/rzuty_rzut_ukosny.htm

27. ILR-33 Bursztyn, Wikipedia, The Free Encyclopedia [online], 2019, https://pl.wikipedia.org/wiki/ILR-33_Bursztyn 
28. Samolot MiG-29UB. Książka 1. Układy płatowca, część I, Dowództwo Wojsk Lotniczych i Obrony Powietrznej, Poznań, 1991

29. Raymer D., Aircraft Design: A Conceptual Approach, 2nd Ed., American Institute of Aeronautics and Astronautics, Inc., Washington, DC, 1992

30. Rogólski R. I INNI, Modelowanie struktury i aerodynamiki samolotów bojowych eksploatowanych $w$ siłach powietrznych $R P$ do analizy flatteru z uwzglednieniem remontowych napraw płatowca sprawozdanie z pracy badawczej, Wojskowa Akademia Techniczna im. Jarosława Dąbrowskiego, Warszawa, 2008

31. Technisches Handbuch. Grundmasse und Ladedaten MiG-29, Luftwaffenmaterialkommando, 1994

32. Analiza wymiarowa, Wikipedia, The Free Encyclopedia [online], 2020, https://pl.wikipedia.org/wiki/Analiza_wymiarowa

33. Samolot MiG-29UB. Instrukcja Techniki Pilotowania, Dowództwo Wojsk Lotniczych i Obrony Powietrznej, Poznań, 1992

34. Aircraft Performance Program APP, Aircraft Performance Software by ALR Aerospace, [online], 2020, https://aircraftperformance.software/

35. APP 6.0 User Manual (2016), ALR Aerospace, Zurich

36. Raymer D., Aircraft Design: A Conceptual Approach, 5th Ed., American Institute of Aeronautics and Astronautics, Inc., Reston, Virginia, 2012

37. Marzocca P., AE-429 Aircraft Peformance and Flight Mechanics. AE-429-5 Aerodynamics of the Airplane Pt. 3, Clarkson University, [online], 2020, https://people.clarkson.edu/ pmarzocc/AE429/AE-429-5.pdf

38. BARTnicki P., Modelowanie geometrii lotniczo-rakietowego systemu wynoszenia ładunków orbitalnych do parametryzacji wybranych własności aeromechanicznych, Praca dyplomowa magisterska, WML WAT, Warszawa, 2020

\section{Preliminary design of a mission profile of an aircraft-rocket vehicle for transporting micro-satellites into the low earth orbit}

The purpose of considerations presented in this study was to initially determine the mission profile for the air-missile orbital discharge system and to assess the possibility of using MiG-29 fighter as a rocket carrier with a useful charge. The concept of transporting miniature satellites by means of rockets launched from airplanes after reaching a certain ceiling becomes more and more attractive due to progressive miniaturization of electronic devices (and thus the carried out objects), which entails an increase in the profitability of such undertakings. The mission outline presented is based on similar historical concepts. Using the relevant operational documentation of MiG-29 aircraft, the fuel consumption in flight with a hypothetical rocket was analytically estimated. Additionally, with the help of a specialized simulation environment of the Aircraft Performance Program (APP), the profile of the mission in flight with a real ILR-33 Amber rocket was examined, obtaining fuel consumption values very similar to those determined by analytical methods. In both cases, MiG-29 aircraft consumes approximately $50 \%$ of the initial amount of fuel, which proves that in this respect there is an undoubted potential for using this fighter in the perspective of the mission program. 